\title{
A dual-acting 5-HT 6 receptor inverse agonist/MAO-B inhibitor displays glioprotective and pro-cognitive properties
}

\author{
Vittorio Canale, ${ }^{\text {a }}$ Katarzyna Grychowska, ${ }^{a}$ Rafał Kurczab, ${ }^{b}$ Mateusz Ryng, ${ }^{b}$ Abdul Raheem \\ Keeri, ${ }^{\mathrm{a}}$ Grzegorz Satała, ${ }^{\mathrm{b}}$ Agnieszka Olejarz-Maciej, ${ }^{\mathrm{c}}$ Paulina Koczurkiewicz, ${ }^{\mathrm{d}}$ Marcin Drop, ${ }^{\mathrm{a}}$ \\ Klaudia Blicharz, ${ }^{\mathrm{a}}$ Kamil Piska, ${ }^{\mathrm{d}}$ Elżbieta Pękala, ${ }^{\mathrm{d}}$ Paulina Janiszewska, ${ }^{\mathrm{e}}$ Martyna Krawczyk, ${ }^{\mathrm{f}}$

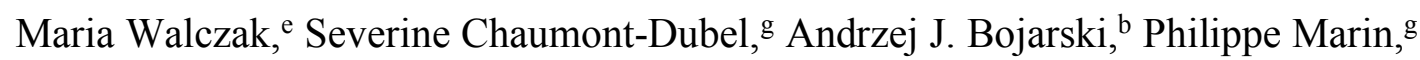 \\ Piotr Popik, ${ }^{\mathrm{f}}$ Paweł Zajdel ${ }^{\mathrm{a}, *}$
}

a Jagiellonian University Medical College, Department of Medicinal Chemistry, ${ }^{c}$ Department of Technology and Biotechnology of Drugs, ${ }^{d}$ Department of Pharmaceutical Biochemistry and ${ }^{e}$ Department of Toxicology, 9 Medyczna Str., 30-688 Kraków, Poland ${ }^{b}$ Maj Institute of Pharmacology, Polish Academy of Sciences, Department of Medicinal Chemistry, ${ }^{f}$ Department of New Drug Development, 12 Smętna Str., 31-324 Kraków, Poland ${ }^{g}$ Institut de Génomique Fonctionelle, Université de Montpellier, CNRS INSERM, 34094 Montpellier, France

*Corresponding author:

Paweł Zajdel

Department of Medicinal Chemistry

Jagiellonian University Medical College

E-mail: pawel.zajdel@uj.edu.pl

Tel.: +48 126205450 


\begin{abstract}
The complex etiology of Alzheimer's disease has initiated a quest for multi-target ligands to address the multifactorial causes of this neurodegenerative disorder. In this context, we designed dual-acting 5- $\mathrm{HT}_{6}$ receptor $\left(5-\mathrm{HT}_{6} \mathrm{R}\right)$ antagonists/MAO-B inhibitors using pharmacophore hybridization strategy. Our approach involved linking 5- $\mathrm{HT}_{6} \mathrm{R}$ scaffolds with aryloxy fragments derived from reversible and irreversible MAO-B inhibitors. The study identified compound 48 that acts as an inverse agonist of 5- $\mathrm{HT}_{6} \mathrm{R}$ at $\mathrm{G}_{\mathrm{s}}$ signaling and an irreversible MAO-B inhibitor. Compound 48 showed moderate metabolic stability in rat microsomal assay and artificial membrane permeability, and it was well distributed to the brain. Additionally, $\mathbf{4 8}$ showed glioprotective properties in a model of cultured astrocytes using 6OHDA as the cytotoxic agent. Finally, compound $48(\mathrm{MED}=1 \mathrm{mg} / \mathrm{kg}$, p.o.) fully reversed memory deficits in the NOR task induced by scopolamine in rats. A better understanding of effects exerted by dual-acting 5- $\mathrm{HT}_{6} \mathrm{R} / \mathrm{MAO}-\mathrm{B}$ modulators may impact the future development of neurodegenerative-directed treatment strategies.
\end{abstract}

\title{
Key words
}

neurodegenerative disorders, Alzheimer's disease, MAO-B inhibitors, 5- $\mathrm{HT}_{6} \mathrm{R}$ antagonists, multi-target directed ligands, constitutive activity, glia, cognition 


\section{Introduction}

Neurodegenerative diseases are chronic conditions which involve progressive loss of neuronal and glial cells, demyelination, and overall structural and functional brain deficits. Among these diseases, Alzheimer's disease (AD) is the most common disorder characterized by continuous deterioration of cognitive functions, resulting in complete disability in the elderly life. The increasing prevalence of $\mathrm{AD}$, together with the lack of effective therapy that could slow down the progression of the disease, makes it one of the biggest global health challenge 0

Unfortunately, therapeutically useful disease-modifying and symptomatic drug candidates for $\mathrm{AD}$ developed in the two past decades have shown disappointing results. ${ }^{1-3}$ Nonetheless, our understanding of $\mathrm{G}$ protein-coupled receptors (GPCRs) signaling networks, and compensatory mechanisms related to enzyme inhibition ${ }^{4}$ and disease pathology steadily grew, thereby opening new opportunities for drug discovery. In particular, more focus was given to develop new strategies using multi-target directed ligands (MTDL) to address the etiology and symptoms of such a complex and debilitating disease. Accumulating evidence revealed that connecting and/or merging structural fragments, which simultaneously affect different biological targets, is one of the most promising areas of anti-AD drug development. ${ }^{5,6}$ Several MTDLs have been reported, with the most prominent examples being dual enzymatic inhibition of acetylcholinesterase (AChE) and glycogen synthase kinase (GSK-3 $\beta),{ }^{7}$ inhibition of AChE and monoamine oxidase B $(0)^{8}$ and inhibition of $\beta$-secretase (BACE-1) and GSK-3 $\beta .{ }^{9}$ The MTDL strategy is further completed with GPCRs dual-acting compounds as $5-\mathrm{HT}_{6} / \mathrm{D}_{3}$ and 5$\mathrm{HT}_{2 \mathrm{~A}} / 5-\mathrm{HT}_{6}$ receptor antagonists ${ }^{10-13}$ as well as $5-\mathrm{HT}_{4} \mathrm{R}$ agonist/5- $\mathrm{HT}_{6} \mathrm{R}$ antagonist. ${ }^{14}$ However, simultaneous targeting of enzyme and receptor activities constitutes a more challenging area. This stems from limitations in finding common binding modes and structural features for targets with different location and structural requirements. ${ }^{15}$ Among examples of such an approach, the dual-acting compounds described thus far include AchE inhibitors and NMDA receptor antagonists, ${ }^{16} \mathrm{AChE}$ and histamine $\mathrm{H}_{3}$ receptor $\left(\mathrm{H}_{3} \mathrm{R}\right)$ antagonists, ${ }^{17} \mathrm{AChE}$ inhibitors and sigma $\sigma_{1}$ receptor ligands, ${ }^{18} \mathrm{AChE}$ inhibitors and serotonin 5-HT $4 \mathrm{R}$ agonists ${ }^{19}$ or AChE inhibitors and 5- $\mathrm{HT}_{6} \mathrm{R}$ antagonists. ${ }^{20}$

Serotonin type 6 receptor $\left(5-\mathrm{HT}_{6} \mathrm{R}\right)$ is a GPCR which has emerged as a promising target for the treatment of pro-cognitive deficits of neurodegenerative and psychiatric disorders. It is almost exclusively expressed in the central nervous system (CNS), particularly in brain regions involved in cognitive processes, i.e., prefrontal cortex, hippocampus and striatum. $5-\mathrm{HT}_{6} \mathrm{R}$ is 
primarily located in the cilia of neurons which are sensory organelles that participate in neurodevelopment and neuronal differentiation. ${ }^{21-24}$

Pharmacological blockade of 5- $\mathrm{HT}_{6} \mathrm{R}$, located on GABA-ergic and glutamatergic neurons, increases cholinergic transmission. ${ }^{25,26}$ Consequently, 5- $\mathrm{HT}_{6} \mathrm{R}$ antagonists show beneficial effects on cognition, as shown by a various preclinical studies and preliminary clinical studies ${ }^{27-}$ ${ }^{29}$ that revealed pro-cognitive effects in humans. ${ }^{30}$ However, phase III clinical trials for these compounds showed disappointing results.

The recent findings on the elevated level of MAO-B in AD brains, corroborated by data showing a MAO-B-dependent control of amyloid- $\beta$ production in neurons via $\gamma$-secretase, suggest a role of MAO-B in AD. ${ }^{31}$ MAO-B is mainly found in the outer membrane of the mitochondria in non-neuronal cells, such as glial cells00000 It is a membrane-bound FADcontaining enzyme, involved in the degradation of monoamines, including dopamine. It has been demonstrated that the production of reactive oxygen species, resulting from the activity of MAO-B, increases with age. Furthermore, an elevated level of this enzyme has been found in astrocytes and pyramidal neurons of AD brains. ${ }^{31,33}$ Based on these observations, MAO-B inhibitors have been investigated as potential neuroprotective agents for the treatment of neurodegenerative disorders. ${ }^{34}$

5- $\mathrm{HT}_{6} \mathrm{R}$ antagonism MAO-B inhibition

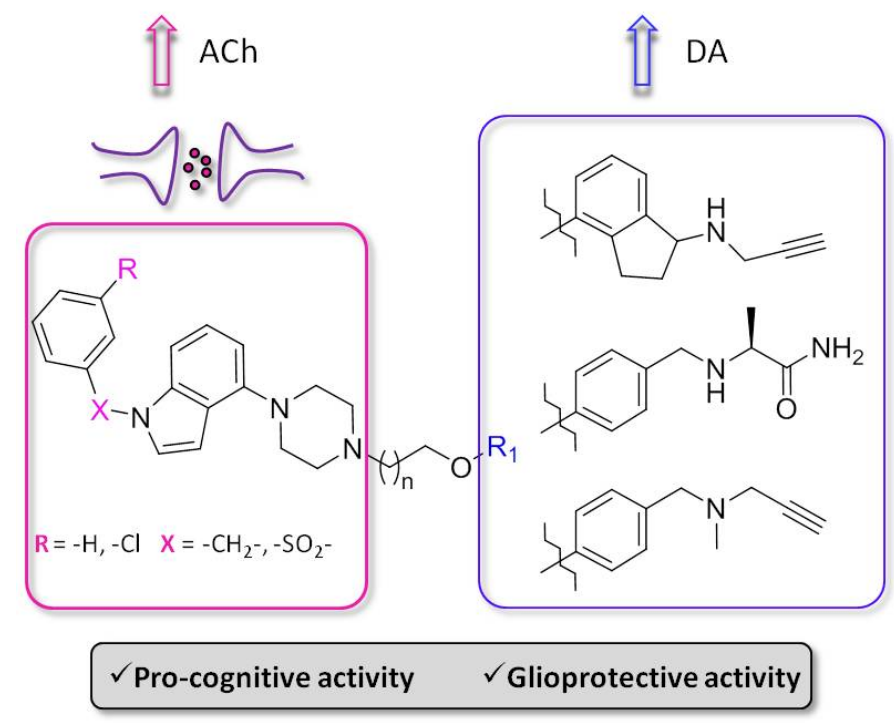

Figure 1. The design strategy of dual-acting 5-HT 6 R/MAO-B modulators.

To determine how to target two distinct proteins with different pharmacophore requirements, we analyzed the binding mode in the $5-\mathrm{HT}_{6} \mathrm{R}$ homology model and sought opportunities to 
target MAO-B catalytic center using induced fit-docking (IFD) and quantum mechanics/molecular mechanics (QM/MM) calculations. This prospective in silico analysis, guided the design and synthesize a new series of hybrid compounds obtained by linking pharmacophore fragments of 5- $\mathrm{HT}_{6} \mathrm{R}$ antagonists with molecular frameworks of known MAO$\mathrm{B}$ inhibitors in a unique molecular entity (Fig. 1). Structural modifications comprised functionalization of $N 1$ atom of (indol-4-yl)piperazine with 3-chlorobenzyl and benzenesulfonyl moieties in the 5- $\mathrm{HT}_{6} \mathrm{R}$ substructure and diversification of aryloxy fragments derived from reversible and irreversible MAO-B inhibitors, both connected via an alkylene spacer of different length. The alaninamide and propargyl moieties were chosen as the moieties able to interact this FAD fragment in the enzymatic cleft of MAO-B. Here, we evaluated the structure-activity relationship (SAR) within novel dual-acting compounds exhibiting inhibitory activity for 5-HT 6 R and MAO-B. We selected a lead compound (compound 48), for which we performed more detailed mechanistic studies. We assessed its action on both targets and examined its distribution to the CNS following peripheral administration. Finally, we showed that this dual 5- $\mathrm{HT}_{6} \mathrm{R}$ inverse agonist/MAO-B inhibitor protects astrocytes against 6hydroxydopamine (6-OHDA)-induced toxicity and reverses scopolamine-induced cognitive impairment in the novel object recognition (NOR) task in rats.

\section{Chemistry}

The designed compounds were synthesized in two stages. First, the respective building blocks, namely functionalized (indol-4-yl)piperazine 5 and 6 (Scheme 1A) and alkylating agents 9-17 (Scheme 1B), were obtained using parallel synthetic routes. Commercially available 4-bromoindole 1 was subjected to Buchwald-Hartwig $N$-arylation to yield 4-(4-Bocpiperazin-1-yl)indole. Simple heating of the obtained product in ethanol at $150{ }^{\circ} \mathrm{C}$ using microwave irradiation eliminated Boc protecting function and provided $1 \mathrm{H}$-indole intermediate 2. This was subsequently reacted with 3-chlorobenzyl bromide or benzenesulfonyl chloride, in the presence of phosphazene base (BTPP) to afford indoles 3 and $\mathbf{4}$. Treatment of the latter compounds with TFA furnished secondary amines $\mathbf{5}$ and $\mathbf{6}$, respectively. 

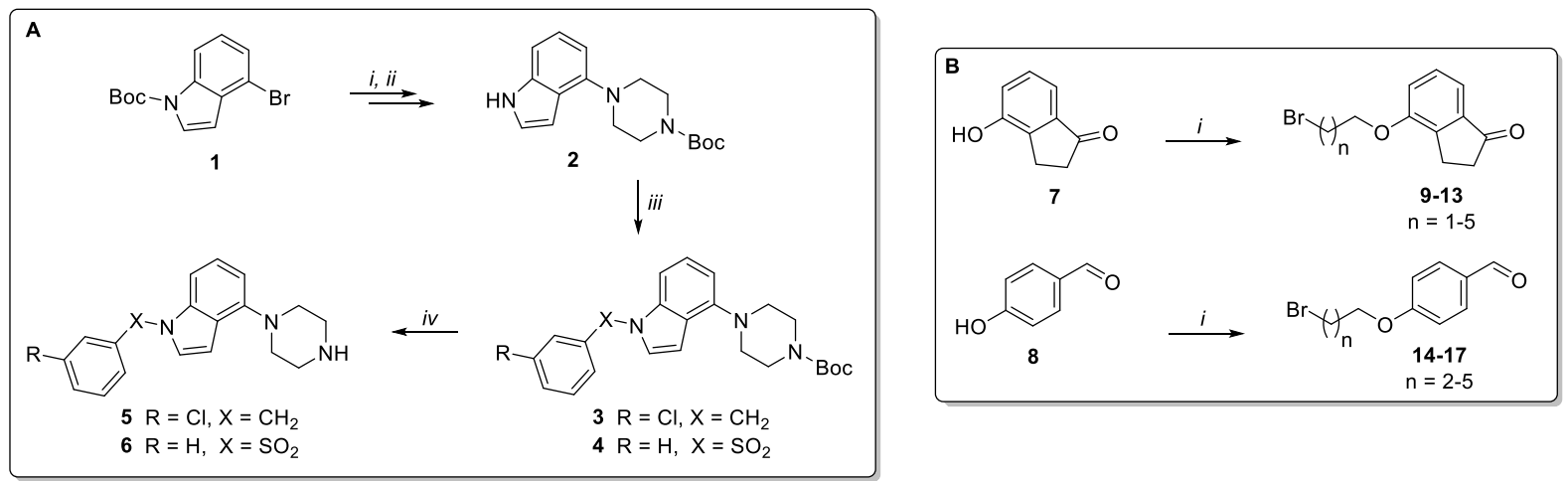

Scheme 1. A: synthesis of 4-piperazine-indole cores 5 and 6. Reagents and conditions: $i$ ) Bocpiperazine, $\mathrm{Pd}_{2}(\mathrm{dba})_{3}$, BINAP, $t$-BuONa, toluen, $110{ }^{\circ} \mathrm{C}, 5 \mathrm{~h}$; ii) $\mathrm{EtOH}, 150{ }^{\circ} \mathrm{C}, \mathrm{MW}, 2 \mathrm{~h}$; iii) 3-chlorobenzyl bromide or benzylsulfonyl chloride, BTPP, DCM, $0^{\circ} \mathrm{C} \rightarrow \mathrm{rt}, 2 \mathrm{~h} ; i v$ ) TFA/DCM, $2 / 8 v / v, \mathrm{rt}, 1 \mathrm{~h}$; B: synthesis of alkylating agents 9-17; i) $\alpha, \omega$-dibromoalkane, $\mathrm{K}_{2} \mathrm{CO}_{3}, \mathrm{KOH}, \mathrm{KI}$, acetone, $60{ }^{\circ} \mathrm{C}, 16 \mathrm{~h}$.

In parallel, commercially available phenols $\mathbf{7}$ and $\mathbf{8}$ were reacted with an excess of different $\alpha, \omega$-dibromoalkane in biphasic conditions, to give respective alkylating agents 9-17 (Scheme 2). Intermediates 9-17 were subsequently combined with secondary amines $\mathbf{5}$ and $\mathbf{6}$, yielding derivatives 18-30, by stirring in acetone at $60^{\circ} \mathrm{C}$, in the biphasic system, for $16 \mathrm{~h}$.

Final compounds 31-48 were obtained by reductive amination, using sodium triacetoxyborohydride (STAB) in THF for primary amines or STAB in DCM for secondary amines.

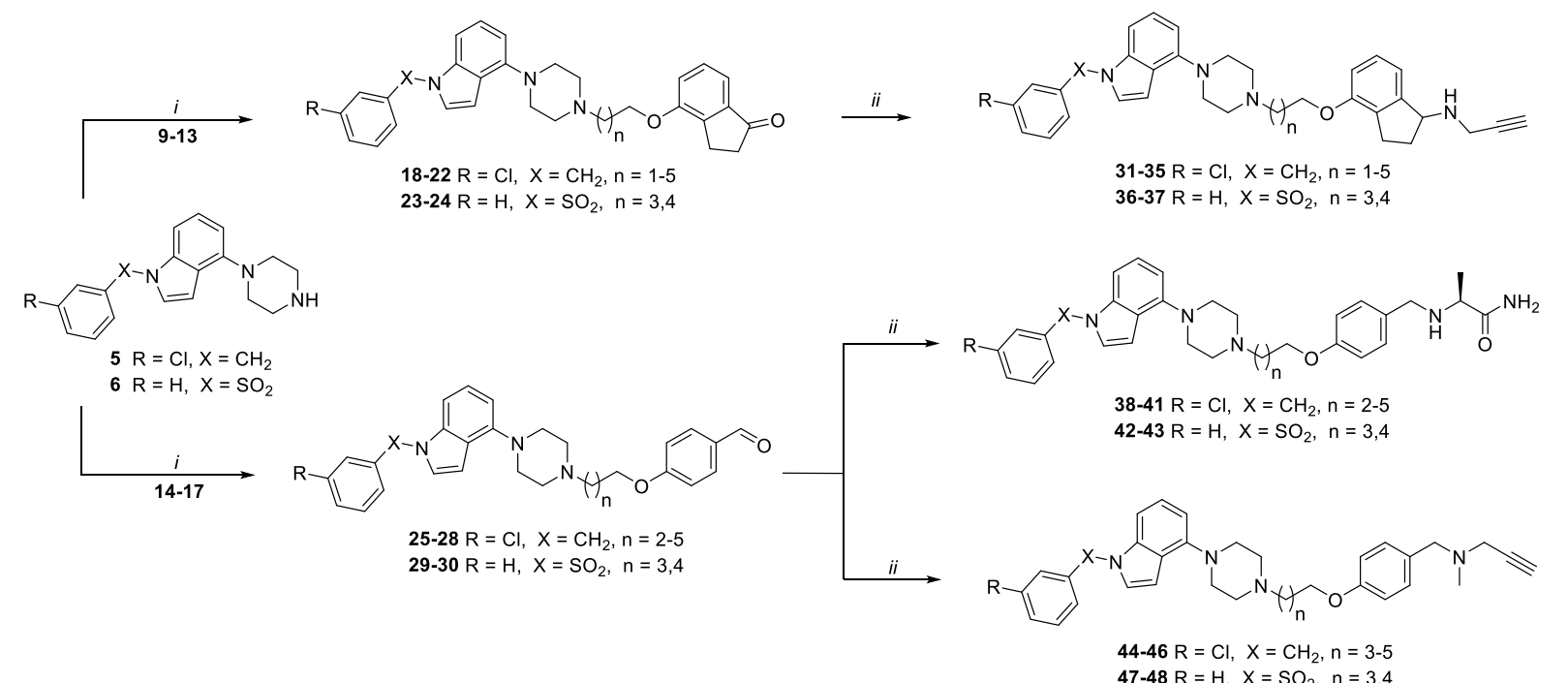

Scheme 2. Synthesis of final compounds 31-48. Reagents and conditions: $i$ ) alkylating agent 9-13 or 14-17, $\mathrm{K}_{2} \mathrm{CO}_{3}, \mathrm{KI}$, acetone, $60^{\circ} \mathrm{C}, 16 \mathrm{~h}$; ii) for primary amine: $\mathrm{AcOH}, \mathrm{THF}_{\mathrm{anh}}, \mathrm{rt}, 5 \mathrm{~h}$ then STAB, rt, $2 \mathrm{~h}$; for secondary amine, AcOH, DCManh, $0.5 \mathrm{~h}$ then STAB, rt, $2 \mathrm{~h}$.

\section{Results and discussion}




\subsection{Structure-activity relationship studies}

The molecular framework of the dual-acting derivatives was based on the pharmacophore hybridization strategy supported with prospective in silico analysis of homology model of 5$\mathrm{HT}_{6} \mathrm{R}$ and crystal structure of MAO-B. The strategy involved connecting pharmacophore structures of known selective 5- $\mathrm{HT}_{6} \mathrm{R}$ antagonists and MAO-B inhibitors in a single molecule. The selection of phenylsulfonyl-4-(piperazin-1-yl)-1H-indole (A) and N-3-chlorobenzyl-4(piperazin-1-yl)indole (B) as 5-HT 6 R-targeting fragments, was based on literature and unpublished data. Our data indicated that compounds containing unsubstituted phenylsulfonyl moiety are highly potent $5-\mathrm{HT}_{6} \mathrm{R}$ ligands, whereas their benzyl analogs require substitution with a chlorine atom in the meta position. ${ }^{35}$

To achieve inhibition of MAO-B activity, aryloxy fragments derived from rasagiline, safinamide and pargyline were linked to the $5-\mathrm{HT}_{6} \mathrm{R}$ pharmacophore via different length alkylene linker. Although the molecular framework of the designed hybrids is different from that of classical MAO-B inhibitors (they are very long, with two basic centers and a flexible alkylene linker), the possibility of interaction with the catalytic domain of MAO-B was supported by in silico experiments. Indeed, molecular dynamics studies indicated the existence of two entrance channels to the MAO-B binding site for inhibitors (more details in SI), i.e., membrane accessed (A), and solvent accessed (B). ${ }^{36}$ An analysis of ligand-enzyme complexes for MAO-B crystals showed that entrance A is closed for several compounds, whereas entrance $\mathrm{B}$ forms a narrow channel. IFD for the designed compounds provided a static view of the conformation of the enzyme, showing that the only way to enter the catalytic center is through entrance $B$, which is devoid of significant steric hindrances. It should be emphasized here that such large compounds would be unable to enter the catalytic MAO-B through entrance A, because it would be sterically disturbed by the mitochondrial membrane.

The newly synthesized compounds 31-48 showed moderate affinity for 5- $\mathrm{HT}_{6} \mathrm{R}$ in ${ }^{3}[\mathrm{H}]$ LSD binding experiments and low-to-high inhibitory potency for MAO-B, with $\mathrm{IC}_{50}$ values ranging from 30 to $>1000 \mathrm{nM}$ as assessed using the fluorimetric method (Table 1). 
Table 1. Affinity for $5-\mathrm{HT}_{6} \mathrm{R}$ and potency for MAO-B inhibition of synthesized compounds 31-48 and reference 5- $\mathrm{HT}_{6} \mathrm{R}$ ligands and MAO-B inhibitors.

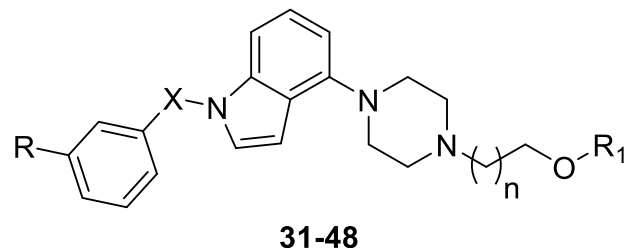

$31-48$<smiles>[R]c1cccc([Y]n2ccc3c(N4CCNCC4)cccc32)c1</smiles>

A $\mathrm{R}=\mathrm{Cl}, \mathrm{X}=\mathrm{CH}_{2}$

B $\mathrm{R}=\mathrm{H}, \quad \mathrm{X}=\mathrm{SO}_{2}$

\begin{tabular}{|c|c|c|c|c|c|c|}
\hline Compd & $\mathbf{R}$ & $\mathbf{X}$ & $\mathbf{n}$ & $\mathbf{R}_{\mathbf{1}}$ & $\begin{array}{c}K_{\mathrm{i}}[\mathrm{nM}]^{\mathrm{a}} \\
h 5-\mathrm{HT}_{6} \mathrm{R}\end{array}$ & $\begin{array}{l}\mathrm{IC} C_{50}[\mathrm{nM}]^{\mathrm{b}} \text { and } \\
(\% \text { inh })^{\mathrm{c}} h \text { MAO-B }\end{array}$ \\
\hline 31 & \multirow{5}{*}{$\mathrm{Cl}$} & \multirow{5}{*}{$\mathrm{CH}_{2}$} & 1 & & 100 & $>1000(35)$ \\
\hline 32 & & & 2 & & 77 & $>1000(31)$ \\
\hline 33 & & & 3 & & 113 & $270 \pm 43(100)$ \\
\hline 34 & & & 4 & & 223 & $460 \pm 51(80)$ \\
\hline 35 & & & 5 & & 259 & $>1000(34)$ \\
\hline 36 & 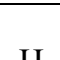 & $\mathrm{SO}$ & 3 & & 50 & $>1000(44)$ \\
\hline 37 & $\mathrm{H}$ & $\mathrm{SU}_{2}$ & 4 & & 51 & $163 \pm 25(90)$ \\
\hline 38 & & & 2 & & 158 & $>1000(47)$ \\
\hline 39 & $C 1$ & $\mathrm{CH}$ & 3 & & 162 & $>1000(24)$ \\
\hline 40 & $C_{1}$ & Сп2 & 4 & & 232 & $>1000(43)$ \\
\hline 41 & & & 5 & & 340 & $>1000(23)$ \\
\hline 42 & $\mathrm{H}$ & $\mathrm{SO}$ & 3 & & 68 & $>1000(20)$ \\
\hline 43 & $\Pi$ & $\mathrm{SO}_{2}$ & 4 & & 65 & $>1000(17)$ \\
\hline 44 & & & 3 & & 195 & $323 \pm 42(85)$ \\
\hline 45 & $\mathrm{Cl}$ & $\mathrm{CH}_{2}$ & 4 & & 140 & $30 \pm 2(100)$ \\
\hline 46 & & & 5 & & 137 & $>1000(32)$ \\
\hline 47 & $\mathrm{H}$ & $\mathrm{SO}$ & 3 & & 54 & $>1000(51)$ \\
\hline 48 & & $\mathrm{SU}_{2}$ & 4 & & 38 & $154 \pm 19(91)$ \\
\hline $\mathbf{A}$ & $\mathrm{Cl}$ & $\mathrm{CH}_{2}$ & & & 7 & (3) \\
\hline B & $\mathrm{H}$ & $\mathrm{SO}_{2}$ & & & 0.3 & (3) \\
\hline Intepirdine $^{\mathrm{d}}$ & & & & & 1.4 & - \\
\hline Rasagiline & & & & & - & $15.4 \pm 0.6(100)$ \\
\hline Safinamide & & & & & - & $7 \pm 1.2(100)$ \\
\hline
\end{tabular}

${ }^{a}$ Mean $K_{\mathrm{i}}$ values (SEM $\pm 15 \%$ ) based on three independent binding experiments

${ }^{\mathrm{b}} \mathrm{IC}_{50} \pm$ SEMs values were determined using rasagiline $[1 \mu \mathrm{M}]$ as positive control

c $\%$ of inhibition of control (rasagiline, $1 \mu \mathrm{M}$ ) at $1 \mu \mathrm{M}$

${ }^{\mathrm{d}}$ Data taken from ${ }^{28}$

Generally, linking 5- $\mathrm{HT}_{6} \mathrm{R}$ pharmacophores with MAO-B-targeting fragments decreased affinity for 5- $\mathrm{HT}_{6} \mathrm{R}$ when compared with the parent compounds $\mathbf{A}$ and $\mathbf{B}$. However, this modification did not totally preclude the interaction of the obtained derivatives with the binding 
cavity of $5-\mathrm{HT}_{6} \mathrm{R}\left(K_{\mathrm{i}}=38-340 \mathrm{nM}\right)$. Compounds bearing $N 1$-sulfonyl moiety were more potent $5-\mathrm{HT}_{6} \mathrm{R}$ ligands than their congeners with methylene bridge, regardless of the length of the alkylene linker and the kind of MAO-B fragment (34 vs 37 and 44 vs 47). Analysis of the obtained ligand-receptor complexes for compound 48 exhibiting the highest affinity for 5- $\mathrm{HT}_{6} \mathrm{R}$ (Fig. 2A), showed that the protonated piperazine fragment formed a salt bridge with D3.32, the indole ring was positioned in the conserved aromatic cluster of F6.51 and F6.52, and the terminal phenyl ring was accommodated in a hydrophobic cavity formed by transmembrane domains 3-5 and extracellular loop 2. It should be noted that the indole and phenyl rings form an angle of approximately $90^{\circ}$, resulting from the tetrahedral geometry $\left(\mathrm{sp}^{3}\right)$ of sulfonyl linkers. In turn, the propargyl moiety at the aryloxy fragment was directed toward the extracellular part of the receptor, with the phenyl ring positioned between N2.63 and W7.39, and protonated the $N$-methyl-propargylamine forming a salt bridge with D7.35.

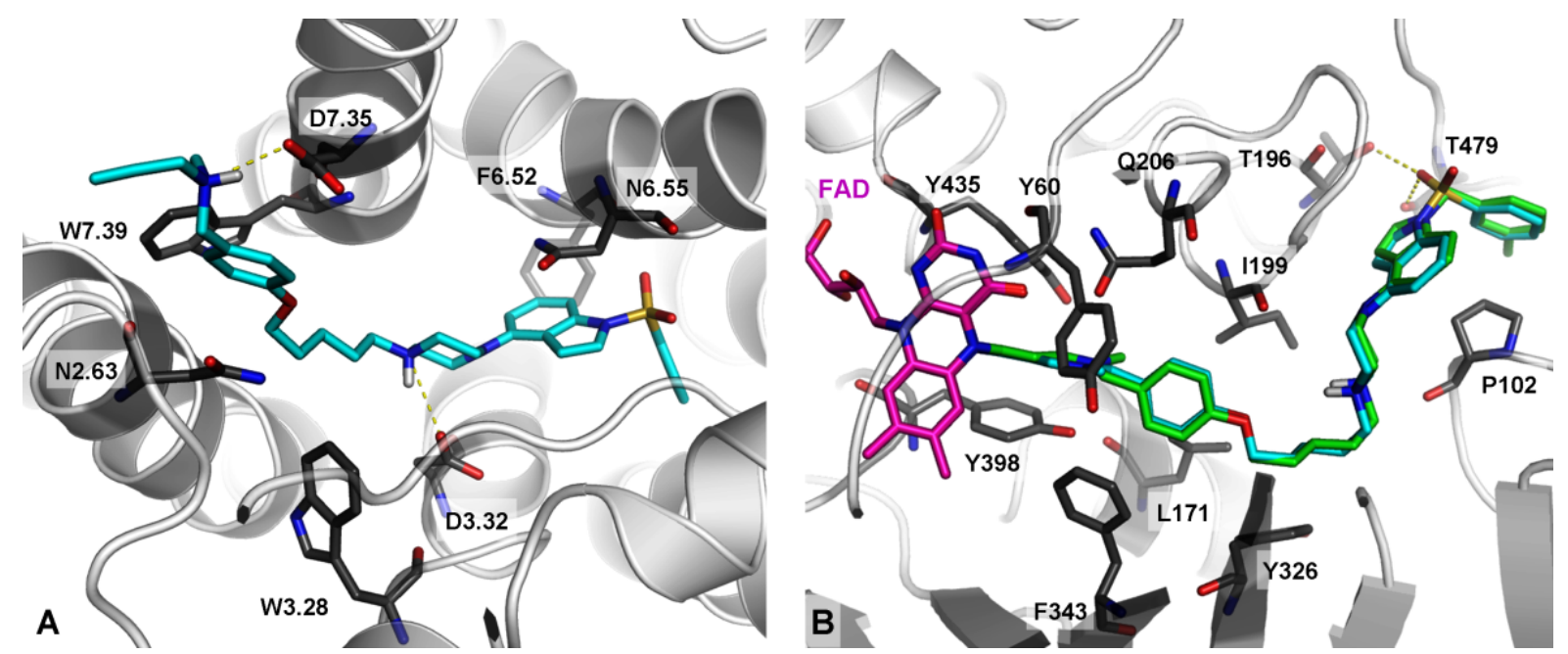

Figure 2. The binding mode of $\mathbf{4 8}$ (cyan) in 5- $\mathrm{HT}_{6} \mathrm{R}$ (A), and comparison of binding modes of 45 (green) and 48 (cyan) in the MAO-B catalytic site (B).

Exploration of SAR toward MAO-B revealed that sulfonamide derivatives were less preferred for the interaction with the enzymatic target than their benzyl analogs (33 vs 36, 40 $v s \mathbf{4 3}$, and 44 vs 47). With regard to the length of the alkylene chain, four and five methylene linked hybrids $(\mathbf{4 0}, \mathbf{3 3})$ exhibited the highest inhibition activity ranging from $73 \%$ to $100 \%$ in all evaluated series. More detailed analysis of the aryloxy terminal fragment, indicated that compounds 38-43 bearing safinamide-derived alaninamide moiety, showed low inhibitory potency against enzyme. On the other hand, the presence of propargyl- and $N$-methylpropargylamine (originated from rasagiline and pargyline, respectively) increased the inhibitory effect (31-100\% inhibition), thus highlighting the pivotal role of covalent bond 
formation of compounds $33, \mathbf{3 7}, \mathbf{4 5}$ and $\mathbf{4 8}$ with FAD cofactor in the enzymatic target. This observation was further confirmed by in silico studies. The binding modes of the most potent MAO-B inhibitors 45 and 48 (Fig. 2B) were coherent and showed accommodation of the molecules in an "aromatic cage" formed by Y435, Y398, Y60, and F343, which are considered crucial in the ligand positioning for the reaction with FAD. ${ }^{37-39}$ Additionally, the hydrogen bond between the side chain of Q206 and the nitrogen atom of the propargyl functional group seems to play a role in placing this fragment in an optimal position. ${ }^{39}$

\subsection{Determination of selectivity profile for compound $\mathbf{4 8}$}

The SAR analysis allowed to identify the most potent dual-acting compound $\mathbf{4 8}$ possessing a phenylsulfonyl moiety at (indol-4-yl)piperazine scaffold in tandem with aryloxy fragments derived from pargyline, connected via a four methylene spacer $\left(K_{\mathrm{i}} 5-\mathrm{HT}_{6} \mathrm{R}=38 \mathrm{nM}, \mathrm{IC}_{50}\right.$ MAO-B $=154 \mathrm{nM}$ ). Subsequently, compound 48 was profiled in vitro for selectivity over structurally-related GPCRs and MAO-A enzyme isoform (Table 2).

Table 2. Binding data of selected compound 48 and intepirdine for 5-HT $6,5-\mathrm{HT}_{1 \mathrm{~A}}, 5-\mathrm{HT}_{2 \mathrm{~A}}, 5-$ $\mathrm{HT}_{7}$, and $\mathrm{D}_{2} \mathrm{Rs}$ and $\mathrm{IC}_{50}$ values for MAO-B and inhibitory activity at MAO-A.

\begin{tabular}{ccccccccc}
\hline \multirow{2}{*}{ Compd } & \multicolumn{6}{c}{$\boldsymbol{K}_{\mathbf{i}}[\mathbf{n M}]^{\mathbf{a}}$} & & \multicolumn{2}{c}{ IC $_{\mathbf{5 0}} \mathbf{b}^{\mathbf{b}}$} \\
\cline { 2 - 5 } & $\mathbf{5 - H T}_{\mathbf{6}}$ & $\mathbf{5 - H T}_{\mathbf{1 A}}$ & $\mathbf{5 - H T}_{\mathbf{2}}$ & $\mathbf{5 - H T}_{\mathbf{7}}$ & $\mathbf{D}_{\mathbf{2}}$ & & MAO-B & MAO-A \\
\hline $\mathbf{4 8}$ & 38 & 684 & 420 & 7996 & 813 & & 154 & 1037 \\
Intepirdine $^{\mathbf{c}}$ & 1.4 & 2370 & 26 & 14230 & 997 & & $\mathrm{NT}^{\mathrm{d}}$ & $\mathrm{NT}^{\mathrm{d}}$ \\
\hline
\end{tabular}

${ }^{a}$ Mean $K_{\mathrm{i}}$ values $(\mathrm{SEM} \pm 25 \%)$ based on three independent binding experiments

${ }^{\mathrm{b}} \mathrm{IC}_{50} \pm$ SEMs values was determined using rasagiline $[1 \mu \mathrm{M}]$ or clorgyline $[1 \mu \mathrm{M}]$ as positive control for MAO$\mathrm{B}$ and MAO-A, respectively

${ }^{c}$ data taken from ${ }^{28}$

${ }^{\mathrm{d}}$ Not Tested

Compound 48 showed moderate to high selectivity over 5- $\mathrm{HT}_{1 \mathrm{~A}}, 5-\mathrm{HT}_{2 \mathrm{~A}}$, $5-\mathrm{HT}_{7}$, and $\mathrm{D}_{2}$ receptors. Although it contains aryloxy fragments derived from pargyline (a known non-selective MAO inhibitor), it showed moderate inhibitory activity toward the MAOA enzyme isoform, thus reducing the possibility to elicit cardiovascular side effects (i.e., hypertensive crisis).

To exclude potential risks related to undesired cardiovascular or CNS side effects, the affinity of compound $\mathbf{4 8}$ for selected "off-target" receptors was assessed by Eurofins Scientific. The tested compound displayed low affinity for $\alpha_{1 \mathrm{~A}}$ adrenoreceptor ( $\%$ inhibition at 1 
$\mu \mathrm{M}=37 \%)$ and did not bind to $\beta_{1}$ adrenoreceptor ( $\%$ inhibition at $1 \mu \mathrm{M}=5 \%$ ), $\mathrm{H}_{1}$ histaminic receptor (\% inhibition at $1 \mu \mathrm{M}=13 \%)$ and $\mathrm{M}_{1}$ muscarinic receptor (\% inhibition at 1 $\mu \mathrm{M}=4 \%)$.

\subsection{Impact of compound 48 on 5-HT $R$-operated signaling and on MAO-B activity}

The impact of compound $\mathbf{4 8}$ on adenylate cyclase activity was first examined in 1321N1 cells expressing 5- $\mathrm{HT}_{6} \mathrm{R}$ and treated with 5-Carboxamidotryptamine (5-CT), a 5- $\mathrm{HT}_{6} \mathrm{R}$ agonist. Compound 48 behaved as a potent antagonist of $5-\mathrm{HT}_{6} \mathrm{R}$ in this cellular assay $\left(K_{\mathrm{b}}=6 \mathrm{nM}\right.$, Table $3)$.

Table 3. The antagonist property of compound $\mathbf{4 8}$ and intepirdine in $1321 \mathrm{~N} 1$ cells and their functional activity at 5- $\mathrm{HT}_{6} \mathrm{R}$-dependent Gs signaling in NG108-15-based model.

\begin{tabular}{cccl}
\hline \multirow{2}{*}{ Compd } & $\begin{array}{c}\boldsymbol{K}_{\mathbf{b}} \\
{[\mathbf{n M}]^{\mathbf{a}}}\end{array}$ & $\begin{array}{c}\text { IC50 } \\
{[\mathbf{n M}]^{\mathbf{b}}}\end{array}$ & Functional profile $^{\mathbf{5}}$ \\
\cline { 2 - 4 } Intepirdine & \multicolumn{3}{c}{$\mathbf{H T}_{\mathbf{6}}$} \\
\hline $\mathbf{4 8}$ & $6 \pm 1$ & $860 \pm 0.68$ & Inverse Agonist \\
& $1.3 \pm 0.2$ & $97 \pm 0.21$ & Inverse Agonist
\end{tabular}

${ }^{\mathrm{a}}$ Mean $K_{\mathrm{b}} \pm$ SEMs of values obtained in three independent experiments in $1321 \mathrm{~N} 1$ cells

${ }^{\mathrm{b}}$ Mean $\mathrm{IC}_{50} \pm$ SEMs of values obtained in three independent experiments in NG108-15 cells

The high level of constitutive activity of $5-\mathrm{HT}_{6} \mathrm{R}$, defined as the ability of the receptor to adopt an active conformation able to transduce signal in the absence of an agonist, has been demonstrated in both in vitro and ex vivo models. ${ }^{40,41}$ This property opens up the possibility to classify $5-\mathrm{HT}_{6} \mathrm{R}$ ligands as inverse agonists or neutral antagonists. ${ }^{28,42}$

Hence, the ability of compound $\mathbf{4 8}$ to modulate agonist-independent 5 - $\mathrm{HT}_{6} \mathrm{R}$-operated Gs signaling was tested in NG108-15 cells transiently expressing 5-HT6R, a cellular model in which the receptor displays high constitutive activity. ${ }^{41,43}$ We found that compound 48 decreased basal cAMP level in a concentration-dependent manner $\left(\mathrm{IC}_{50}=860 \pm 0.68 \mathrm{nM}\right)$ but its apparent affinity was much lower than that of the prototypic 5- $\mathrm{HT}_{6} \mathrm{R}$ inverse agonist intepirdine (Table 3, Fig. 3). 


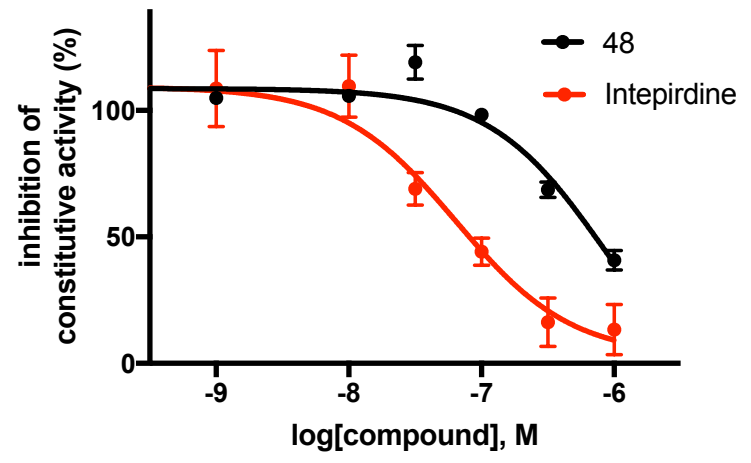

Figure 3. Influence of compound 48 and intepirdine on basal cAMP production in NG108-15 cells transiently expressing $5-\mathrm{HT}_{6}$ Rs. Data are the means \pm SEM of the values obtained in three independent experiments performed in quadruplicate in different sets of cultured cells. ${ }^{* * *} \mathrm{p}<$ $0.001 v s$. vehicle (ANOVA followed by Student-Newman-Keuls test).

To investigate the inhibitory mechanism of compound 48 on $h \mathrm{MAO}-\mathrm{B}$, time-dependent inhibition studies were performed using in vitro method. Rasagiline and safinamide, with known irreversible and reversible inhibition toward MAO-B were used as reference drugs (Fig.4). In the case of reversible inhibitor safinamide, the competing excess of p-tyramine, used as an enzyme substrate, significantly reactivated the enzyme activity. In contrast, rasagiline, depending on the pre-incubation time used, has either slightly restored MAO-B activity or maintained only residual activity of the enzyme. A higher than expected signal for rasagiline without pre-incubation (ca. 30\% reactivation) might be explained by the longer time required to create the covalently bound inhibitor-enzyme complex by irreversible inhibitors. Although compound 48 was able to restore some activity of MAO-B, the difference between the enzyme reactivation rate, obtained with and without pre-incubation, suggests that compound $\mathbf{4 8}$ covalently modify the enzyme.

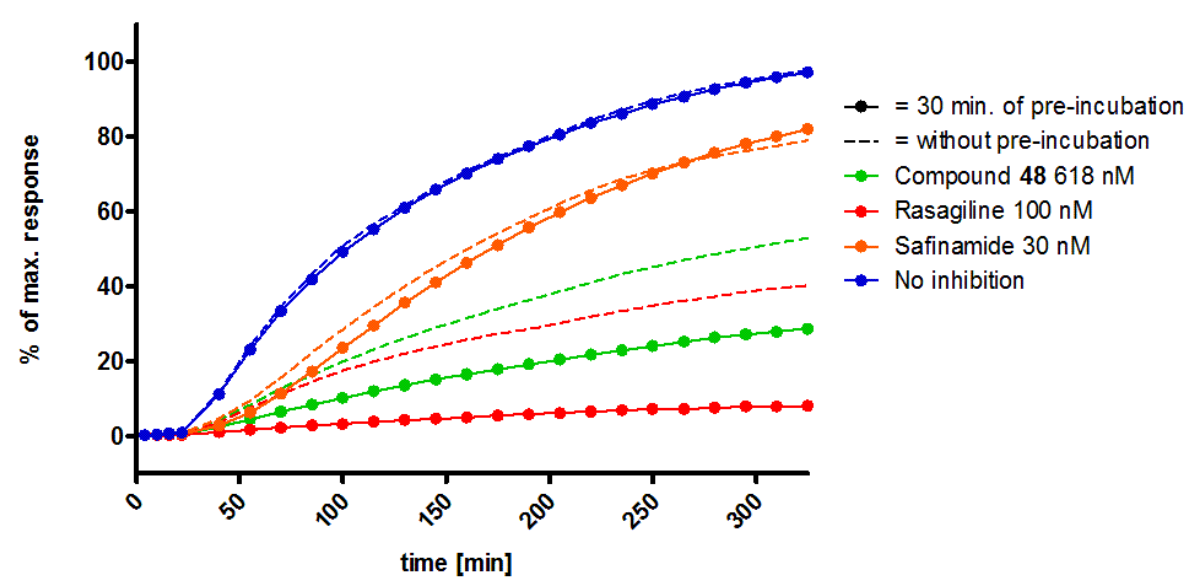

Figure 4. Reactivation of MAO-B activity upon blockade with compound $\mathbf{4 8}$ and reference inhibitors used at a concentrations corresponding to their $\mathrm{IC}_{80}$ values in the presence of the 
substrate p-tyramine. All compounds were tested with $30 \mathrm{~min}$ of pre-incubation (rings) and without pre-incubation (lines). Data are presented as mean values from two independent experiments run in duplicate. The results were normalized to the effect induced by $1 \mathrm{mM}$ of $\mathrm{p}$ tyramine (100\% value) and solvent (0\% value) in the last measurement of the experiment.

\subsection{Preliminary evaluation of ADME properties}

As ligands that combine two pharmacophore fragments within a single molecule usually have physicochemical properties burdens (high molecular weight or clog P value), which might limit their bioavailability, compound $\mathbf{4 8}$ was subsequently evaluated for its drug-likeness in in vitro screening. The ability to cross the blood-brain barrier (BBB) by passive diffusion was assessed by the commonly used parallel artificial membrane permeability assay (PAMPABBB). ${ }^{44}$ Compound 48 showed an efficient permeability (Pe) value greater than 4.0 in the tested conditions, thus suggesting a high CNS penetration (Table 4). The reference drugs verapamil $\left(\mathrm{Pe}=1.85 \times 10^{-5} \mathrm{~cm} / \mathrm{sec}\right)$ and doxorubicin (not detected in the acceptor compartment) were used as positive and negative control, respectively.

Table 4. Summary of the ADME profile evaluation for compound 48

\begin{tabular}{lc}
\hline Assay type & $\mathbf{4 8}$ \\
\hline PAMPA permeability & $\mathrm{Pe}=4.84 \times 10^{-6} \mathrm{~cm} / \mathrm{sec}^{\mathrm{a}}$ \\
Microsomal stability & $\mathrm{Cl}_{\text {int }}=85 \mathrm{ml} / \mathrm{min} / \mathrm{kg}^{\mathrm{b}}$ \\
\hline $\begin{array}{c}\text { Preliminary in vivo } \\
\text { pharmacokinetics }\end{array}$ & $\mathrm{C}_{\max }=72.7 \mathrm{ng} / \mathrm{mL}$ \\
$\mathrm{T}_{\max }=30 \mathrm{~min}$ \\
\hline${ }^{\mathrm{a}}$ measured at $100 \mu \mathrm{M}$ initial concentration at $\mathrm{pH} 7.4$ in a phosphate buffer at room \\
temperature measured at pH 7.4 in a phosphate buffer at room temperature \\
$\begin{array}{l}{ }^{\mathrm{b}} \text { determined at a protein concentration of } 0.4 \mathrm{mg} / \mathrm{ml} \text { in RLM assay } \\
{ }^{\mathrm{c}} \text { measured after } p . \text { o. administration of dose } 3 \mathrm{mg} / \mathrm{kg} .\end{array}$
\end{tabular}

Subsequently, the in vitro metabolic stability of compound $\mathbf{4 8}$ was determined using rat liver microsomes (RLMs). After 60-min incubation period, the compound $\mathbf{4 8}$ showed an average intrinsic clearance $\left(\mathrm{Cl}_{\text {int }}\right)$ of $85 \mathrm{~mL} / \mathrm{min} / \mathrm{kg}$ (Table 4$)$.

Next, the preliminary pharmacokinetic profile of compound 48 was estimated in male Wistar rats injected with a single dose ( $3 \mathrm{mg} / \mathrm{kg}$ p.o.). Compound 48 was rapidly absorbed and was able to cross the $\mathrm{BBB}$ with a $\mathrm{C}_{\max }$ value reaching $72.7 \mathrm{ng} / \mathrm{mL}$ in the brain after $30 \mathrm{~min}$ ( $\mathrm{T}_{\max }$, Table 4). The molecule was eliminated very slowly from the rat body, with along halflife of ca. $28 \mathrm{~h}$. 


\subsection{Glioprotective effects}

Given the supporting role of glial cells in the CNS, protection of astrocytes might be a relevant strategy for treating neurodegenerative disorders in addition to directly act on neuronal cell functions or survival [ref]. We thus explored the glioprotective effects of compound $\mathbf{4 8}$ in a model of cultured astrocytes (C8-D1A astrocytes) exposed to the neurotoxin 6-OHDA. 6OHDA-induced cell death is attributed to the oxidative damage by reactive oxygen species (ROS) derived from 6-OHDA autooxidation or possible direct effect of 6-OHDA on the mitochondrial respiratory chain complex.

As revealed by the MTT assay (which assesses mitochondrial metabolism), compound $\mathbf{4 8}$ did not induce significant toxicity in C8-D1A astrocyte cultures at concentrations up to 50-100 $\mu \mathrm{M}$ but protected C8-D1A astrocytes against 6-OHDA-induced cytotoxicity (Fig. 5A). These observations were confirmed in lactate dehydrogenase (LDH) assay, which assesses cell membrane integrity (Fig. 5B). Notably, intepirdine exhibited no glioprotective properties. ${ }^{11}$ Similarly, although neuroprotective activity of selegiline was established in several in vitro models ${ }^{45-47}$, this irreversible MAO-B inhibitor did not reduce gliotoxicity induced by 6-OHDA in both cell-based assays (Fig. 5A and 5B). These findings suggest that blockade of MAO-B alone is not sufficient to protect C80D1A astrocytes against 6-OHDA toxicity, and that the glioprotective effect of compound 48 results either from $5-\mathrm{HT}_{6}$ receptor antagonist/inverse agonist activity or from its dual inhibitory activities on 5- $\mathrm{HT}_{6} \mathrm{R}$ and MAO-B.

astrocytes

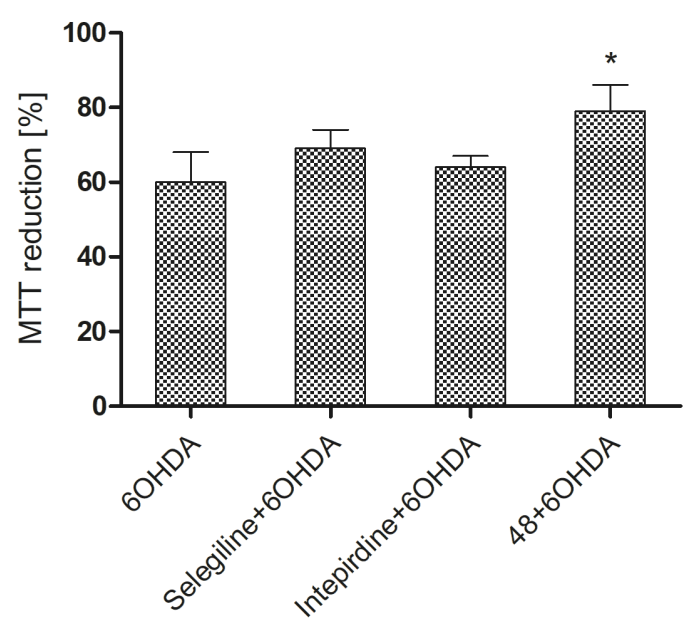

astrocytes

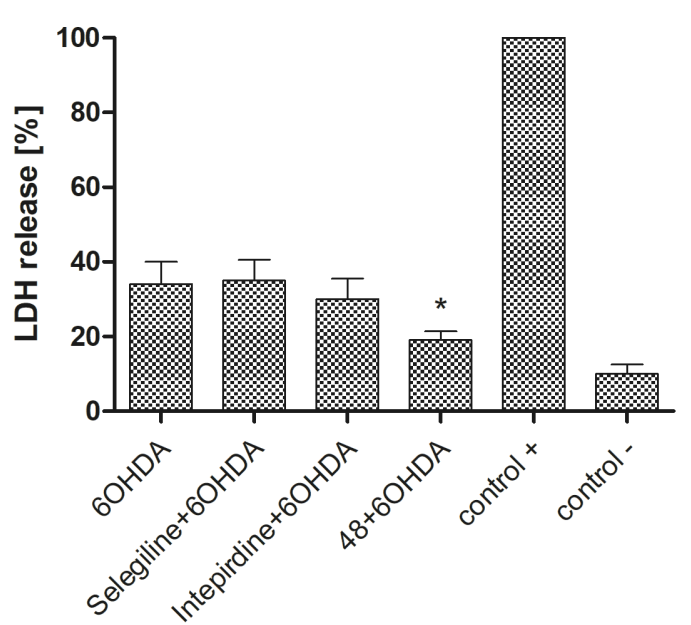

Figure 5. Effect of selegiline, intepirdine, and 48 on 6-OHDA-induced astrocytes cytotoxicity. (A) MTT and (B) LDH assays were performed on astrocytes pre-treated with the tested 
compounds $(0.25 \mu \mathrm{M})$ for $24 \mathrm{~h}$ and injured by 6-OHDA $(25 \mu \mathrm{M})$ for the next 24 -h period. $\mathrm{p}<0.05$ vs 6-OHDA. 


\subsection{Pro-cognitive properties}

Given the interesting multipotent activity of compound $\mathbf{4 8}$, its ability to rescue cognitive deficit induced by scopolamine (SCOP) in rats was then investigated using the NOR test. Scopolamine administration $(1.25 \mathrm{mg} / \mathrm{kg}$, p.o. $)$ abolished the ability of rats to discriminate between novel and familiar objects when compared to the vehicle-treated animals. These deficits were significantly reversed by p.o. administration of compound $\mathbf{4 8}$ at the doses of 1 and $3 \mathrm{mg} / \mathrm{kg}$ (Fig. 6).

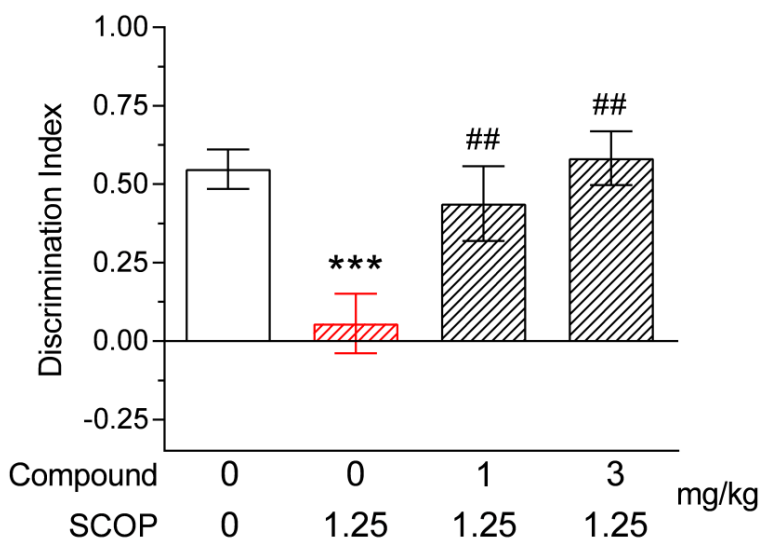

Figure 6. Effects of compound 48 on SCOP-induced inhibition of novelty discrimination in the NOR test in rats. The data illustrated represent discrimination index (DI) and are the mean \pm standard error of the mean of $\mathrm{N}=6-10$ animals per group. Symbols: $* * * \mathrm{p}<0.001 v \mathrm{~s}$ vehicle-treated group; \#\# $\mathrm{p}<0.01$ vs SCOP-treated group.

\section{Conclusions}

Using the strategy of dual-acting compounds, we designed and synthesized a series of hybrids that combine a (indol-4-yl)-piperazine fragment - a well-established core of 5- $\mathrm{HT}_{6} \mathrm{R}$ antagonists - with frameworks of known MAO-B inhibitors, connected through an alkylene linker. In agreement with the design rationale, the majority of novel hybrid compounds showed affinity for 5-HT 6 R and inhibitory activity for the enzyme target. The study identified compound 48, a dual 5- $\mathrm{HT}_{6} \mathrm{R} / \mathrm{MAO}-\mathrm{B}$ modulator, which behaved as an inverse agonist of 5$\mathrm{HT}_{6} \mathrm{R}$ at the $\mathrm{G}_{\mathrm{s}}$ signaling pathway and an irreversible MAO-B inhibitor. Besides showing the most efficient combination of 5- $\mathrm{HT}_{6} \mathrm{R}$ modulation and MAO-B inhibitory activity, compound 48 was metabolically stable and brain penetrant. Moreover, compound 48 reduced the gliotoxic effect of 6-OHDA in C8-D1A astrocytes in two complementary assays (MTT and LDH) 
assessing cell survival. Importantly, this effect was not observed after treatment with intepirdine (5-HT 6 R antagonist) and MAO-B inhibitor selegiline. Finally, compound 48 also reverse cognitive decline induced by scopolamine in the NOR test. These properties highlight $\mathbf{4 8}$ as an original example of dual $5-\mathrm{HT}_{6} \mathrm{R} / \mathrm{MAO}-\mathrm{B}$ modulator and as an interesting prototype in the development of new treatment strategies for AD. 


\section{Experimental procedures}

\subsection{Chemistry}

\subsubsection{General methods}

The synthesis was carried out at ambient temperature, unless indicated otherwise. Organic solvents (from Aldrich and Chempur) were of reagent grade and were used without purification. All reagents (Sigma-Aldrich, Fluorochem, Across and TCI) were of the highest purity. Column chromatography was performed using silica gel Merck 60 (70-230 mesh ASTM).

Mass spectra were recorded on a UPLC-MS/MS system consisted of a Waters ACQUITY ${ }^{\circledR}$ UPLC ${ }^{\circledR}$ (Waters Corporation, Milford, MA, USA) coupled to a Waters TQD mass spectrometer (electrospray ionization mode ESI-tandem quadrupole). Chromatographic separations were carried out using the Acquity UPLC BEH (bridged ethyl hybrid) C18 column; $2.1 \times 100 \mathrm{~mm}$, and $1.7 \mu \mathrm{m}$ particle size, equipped with Acquity UPLC BEH C18 Van Guard pre-column; $2.1 \times 5 \mathrm{~mm}$, and $1.7 \mu \mathrm{m}$ particle size. The column was maintained at $40^{\circ} \mathrm{C}$, and eluted under gradient conditions from $95 \%$ to $0 \%$ of eluent A over $10 \mathrm{~min}$, at a flow rate of 0.3 $\mathrm{mL} \min ^{-1}$. Eluent A: water/formic acid $(0.1 \%, \mathrm{v} / \mathrm{v})$; eluent B: acetonitrile/formic acid $(0.1 \%$, $v / v)$. Chromatograms were made using Waters e $\lambda$ PDA detector. Spectra were analyzed in 200 $700 \mathrm{~nm}$ range with $1.2 \mathrm{~nm}$ resolution and sampling rate 20 points/s. MS detection settings of Waters TQD mass spectrometer were as follows: source temperature $150{ }^{\circ} \mathrm{C}$, desolvation temperature $350^{\circ} \mathrm{C}$, desolvation gas flow rate $600 \mathrm{~L} \mathrm{~h}-1$, cone gas flow $100 \mathrm{~L} \mathrm{~h}-1$, capillary potential $3.00 \mathrm{kV}$, cone potential $40 \mathrm{~V}$. Nitrogen was used for both nebulizing and drying gas. The data were obtained in a scan mode ranging from 50 to $2000 \mathrm{~m} / \mathrm{z}$ in time $1.0 \mathrm{~s}$ intervals. Data acquisition software was MassLynx V 4.1 (Waters). The UPLC/MS purity of all the final compounds was confirmed to be $95 \%$ or higher.

${ }^{1} \mathrm{H}$ NMR and ${ }^{13} \mathrm{C}$ NMR spectra were obtained JOEL JNM-ECZR500 RS1 (ECZR version) at 500 and $126 \mathrm{MHz}$, respectively and are reported in ppm using deuterated solvent for calibration $\left(\mathrm{CDCl}_{3}\right.$ or DMSO- $\left.d_{6}\right)$. The $J$ values are reported in Hertz $(\mathrm{Hz})$, and the splitting patterns are designated as follows: br. s. (broad singlet), s (singlet), d (doublet), t (triplet), q (quartet), dd (doublet of doublets), m (multiplet).

Elemental analysis for $\mathrm{C}, \mathrm{H}, \mathrm{N}$ and $\mathrm{S}$ was carried out using the elemental Vario EI III Elemental Analyser (Hanau, Germany). All values are given as percentages, and were within $\pm 0.4 \%$ of the calculated values.

Compound 48 selected for behavioral evaluation was converted into the hydrochloride salt. 
All synthetic procedures and spectroscopic data for selected final compounds are summarized below, while characterization data for all intermediates and remained final compounds are reported in the Supporting Information.

\subsubsection{General procedure for the $N$-arylation of N-Boc-4-bromo-indole and selective Boc- deprotection (2)}

$N$-Boc-4-bromoindole derivative (5 g, $16.88 \mathrm{mmol}, 1 \mathrm{eq})$, Boc-piperazine (6.28 g, $33.77 \mathrm{mmol}$, $2 \mathrm{eq}$ ), tris(dibenzylideneacetone)dipalladium (310 mg, $0.34 \mathrm{mmol}, 0.02 \mathrm{eq})$. BINAP (420 mg, $0.68 \mathrm{mmol}, 0.04 \mathrm{eq})$ and $\mathrm{NaO} t \mathrm{Bu}(1.77 \mathrm{~g}, 18.38 \mathrm{mmol}, 1.5 \mathrm{eq})$ were solubilized in toluene anhydrous $(30 \mathrm{~mL})$ in a $250 \mathrm{~mL}$ reaction flask. The flask was evacuated and back filled with argon and the reaction was left stirring at $110^{\circ} \mathrm{C}$ for $5 \mathrm{~h}$. Then, the mixture was diluted with AcOEt $(50 \mathrm{~mL})$ and filtered off on Celite pad and finally concentrated. The crude mixture was purified on silica gel using a mixture of $\operatorname{AcOEt} / \operatorname{Hex}(1 / 9, v / v)$ as eluting system. Next, the pure intermediate $(4.3 \mathrm{~g}, 10.71 \mathrm{mmol})$ was dissolved in $\mathrm{EtOH}(80 \mathrm{~mL})$ and portioned in 4 seal-closed microwave reactors. Each reactor was irradiated for $2 \mathrm{~h}$ at $150^{\circ} \mathrm{C}$. Then, organic solvent was removed under vacuum and the resulting product ( $3.07 \mathrm{~g}$, 95\% yield) was pure enough for the next synthetic step.

\subsubsection{General procedure for benzylation or sulfonilation of the $N_{1}$-indole moiety (3-4)}

A solution of tert-butyl 4-(1H-indol-4-yl)piperazine-1-carboxylate (1.5 g, $4.98 \mathrm{mmol}, 1 \mathrm{eq})$ in $\mathrm{CH}_{2} \mathrm{Cl}_{2}(20 \mathrm{~mL})$ was cooled to $0^{\circ} \mathrm{C}$ followed by addition of phosphazene base $\mathrm{P}_{1}-t-\mathrm{Bu}$ tris(tetramethylene) $(2.27 \mathrm{~mL}, 7.47 \mathrm{mmol}, 1.5 \mathrm{eq})$. Then, the mixture was treated with 3-chlorobenzyl bromide $(0.98 \mathrm{~mL}, 7.47 \mathrm{mmol}, 1.5 \mathrm{eq})$ or benzenesulfonyl chloride $(0.95 \mathrm{~mL}$, $7.47 \mathrm{mmol}, 1.5 \mathrm{eq}$ ) and stirred for $2 \mathrm{~h}$ at rt. After removal of organic solvents, the crude products were purified on silica gel using a mixture of AcOEt/Hex as eluting system.

\subsubsection{General procedure for Boc deprotection at piperazine moiety (5-6)}

Intermediate $3(1.45 \mathrm{~g}, 3.4 \mathrm{mmol})$ was solubilized in $\mathrm{CH}_{2} \mathrm{Cl}_{2}(12 \mathrm{~mL})$ and cooled to $0^{\circ} \mathrm{C}$ followed by addition of TFA $(3 \mathrm{~mL})$. The reaction mixture was stirred for $2 \mathrm{~h}$ at $\mathrm{rt}$. Then, the reaction was diluted with $\mathrm{CH}_{2} \mathrm{Cl}_{2}(5 \mathrm{~mL})$ and the acidic excess was carefully neutralized with cold $\mathrm{NH}_{3}$ aqueous solution till $\mathrm{pH}=10$. The organic fraction was washed with brine $(1 \mathrm{x})$, dried over anhydrous $\mathrm{Na}_{2} \mathrm{SO}_{4}$, filtered and concentrated under vacuum. The resulting product 5 was submitted to the next step without further purification. According to the same procedure intermediate $\mathbf{4}$ was converted into secondary amine $\mathbf{6}$.

\subsubsection{General procedure for alkylation of phenols (9-13 and 14-17)}


A suspension of 4-hydroxy-indanone $(0.75 \mathrm{~g}, 5.06 \mathrm{mmol}, 1 \mathrm{eq})$, freshly grinded $\mathrm{K}_{2} \mathrm{CO}_{3}(1.75$ $\mathrm{g}, 12.66 \mathrm{mmol}, 2.5 \mathrm{eq})$ and $\mathrm{KOH}(0.14 \mathrm{~g}, 2.53 \mathrm{mmol}, 0.5 \mathrm{eq})$ in $15 \mathrm{ml}$ of acetone. The proper di-bromoalkane (20.24 mmol, 4 eq) was slowly dropped to the reaction mixture and then left stirring at $60{ }^{\circ} \mathrm{C}$ overnight. Then, inorganic residues were filtered off, followed by removal of organic solvent under vacuum. The crude products were purified on silica gel using a mixture of AcOEt/Hex as eluting system. to obtain intermediates 9-13. The same procedure was employed for the alkylation 4-hydroxybenzaldehyde with different di-bromoalkane to achieve intermediates 14-17.

\subsubsection{General procedure for the alkylation of $N_{1}$-functionalized-4-indol-piperazine (18-30)}

1-(3-Chlorobenzyl)-4-(piperazin-1-yl)-1H-indole 5 (150 mg, $0.46 \mathrm{mmol} 1 \mathrm{eq})$ and freshly grinded $\mathrm{K}_{2} \mathrm{CO}_{3}(190 \mathrm{mg} 1.38 \mathrm{mmol}, 3 \mathrm{eq})$ were suspended in $5 \mathrm{ml}$ of acetone, followed by the dropwise addition of the corresponding alkylating agent 9-17 (0.55 mmol, $1.2 \mathrm{eq})$. The reaction mixture was stirred at $60{ }^{\circ} \mathrm{C}$ overnight. Then, inorganic residues were filtered off, followed by removal of organic solvent under vacuum. The crude products were purified on silica gel using a mixture of $\mathrm{DCM} / \mathrm{MeOH}$ as eluting system, yielding intermediates 18-22 and 25-28. The same procedure was repeated to obtain intermediates 23-24 and 29-30 by alkylation of 1-((3chlorophenyl)sulfonyl)-4-(piperazin-1-yl)- $1 H$-indole with synthesized alkylating agents 11-12 and 15-16, respectively.

\subsubsection{General procedure for reductive amination of ketone with propargyl amine (31-37)}

Ketone derivative 18 (120 mg, $0.2 \mathrm{mmol}, 1 \mathrm{eq})$, and propargyl amine (26 $\mu \mathrm{L}, 0.4 \mathrm{mmol}, 2 \mathrm{eq})$ were solubilized in anhydrous THF $(3 \mathrm{~mL})$ and the mixture was stirred for $5 \mathrm{~h}$. The, the reducing agent STAB (127 mg, $0.6 \mathrm{mmol}, 3 \mathrm{eq}$ ) was added and the mixture was left stirring for additional $2 \mathrm{~h}$. Subsequently, the reaction was quenched with a saturated solution of $\mathrm{NaHCO}_{3}$, washed with $\mathrm{H}_{2} \mathrm{O}(2 \times)$, brine $(1 \times)$, dried over $\mathrm{Na}_{2} \mathrm{SO}_{4}$, filtered and concentrated. The obtained crude product was purified using silica gel with $\mathrm{CH}_{2} \mathrm{Cl}_{2} / \mathrm{MeOH}$ as an eluting system to obtain final compound 31. The same procedure was applied to intermediates 19-24 and for yielding final compounds 32-37.

\subsubsection{General procedure for reductive amination of benzaldehyde with L-alanamide (38-43)}

Benzaldehyde derivative 25 (120 mg, $0.25 \mathrm{mmol}, 1 \mathrm{eq})$, and $L$-alanamide hydrochloride (76 $\mathrm{mg}, 0.5 \mathrm{mmol}, 2 \mathrm{eq})$ were solubilized in anhydrous THF $(3 \mathrm{~mL})$ and the mixture was stirred for $5 \mathrm{~h}$. The, the reducing agent STAB $(158 \mathrm{mg}, 0.75 \mathrm{mmol}, 3 \mathrm{eq})$ was added and the mixture was left stirring for additional $2 \mathrm{~h}$. Subsequently, the reaction was quenched with a saturated solution 
of $\mathrm{NaHCO}_{3}$, washed with $\mathrm{H}_{2} \mathrm{O}(2 \times)$, brine $(1 \times)$, dried over $\mathrm{Na}_{2} \mathrm{SO}_{4}$, filtered and concentrated. The obtained crude product was purified using silica gel with $\mathrm{CH}_{2} \mathrm{Cl}_{2} / \mathrm{MeOH}$ as an eluting system to obtain final compound 38. The same procedure was applied to intermediates $\mathbf{2 6}-\mathbf{3 0}$ for yielding final compounds 39-43.

\subsubsection{General procedure for reductive amination of benzaldehyde with $N$-methyl-propargyl amine (44-48)}

Benzaldehyde derivative 26 (120 mg, $0.24 \mathrm{mmol}, 1 \mathrm{eq}$ ), and $N$-methylpropargyl amine (40 $\mu \mathrm{L}$, $0.48 \mathrm{mmol}, 2 \mathrm{eq})$ were solubilized in $\mathrm{CH}_{2} \mathrm{Cl}_{2}(3 \mathrm{~mL})$ and the mixture was stirred for $30 \mathrm{~min}$. The, the reducing agent STAB (152 mg, $0.72 \mathrm{mmol}, 3 \mathrm{eq}$ ) was added and the mixture was left stirring for additional $1 \mathrm{~h}$. Subsequently, the reaction was quenched with a saturated solution of $\mathrm{NaHCO}_{3}$, washed with $\mathrm{H}_{2} \mathrm{O}(2 \times)$, brine $(1 \times)$, dried over $\mathrm{Na}_{2} \mathrm{SO}_{4}$, filtered and concentrated. The obtained crude product was purified using silica gel with $\mathrm{CH}_{2} \mathrm{Cl}_{2} / \mathrm{MeOH}$ as an eluting system to yield final compound $\mathbf{4 4}$. The same procedure was applied to intermediates 26-30 for yielding final compounds $\mathbf{4 5}-\mathbf{4 8}$.

\subsubsection{Characterization data for selected final compounds}

\subsubsection{4-(4-(4-(1-(3-Chlorobenzyl)-1H-indol-4-yl)piperazin-1-yl)butoxy)-N-(prop-2-yn-1- yl)-2,3-dihydro-1H-inden-1-amine (33)}

Brown oil, $76 \mathrm{mg}$ (isolated yield 59\%) following chromatographic purification over silica gel with $\mathrm{CH}_{2} \mathrm{Cl}_{2} / \mathrm{MeOH}(9 / 1, v / v)$; UPLC/MS purity $98 \%, t_{\mathrm{R}}=5.14, \mathrm{C}_{35} \mathrm{H}_{39} \mathrm{ClN}_{4} \mathrm{O}, \mathrm{MW} 567.17$, Monoisotopic Mass 566.28, $[\mathrm{M}+\mathrm{H}]^{+}$567.4. ${ }^{1} \mathrm{H}$ NMR (500 MHz, $\left.\mathrm{CDCl}_{3}\right) \delta$ ppm $1.27(\mathrm{~m}, 2 \mathrm{H}$, $\left.\mathrm{N}-\mathrm{CH}_{2}-\mathrm{CH}_{2}\right), 1.38-1.44\left(\mathrm{~m}, 1 \mathrm{H}\right.$, indane), $1.72-1.80\left(\mathrm{~m}, 2 \mathrm{H}, \mathrm{O}-\mathrm{CH}_{2}-\mathrm{CH}_{2}\right), 1.81-1.91(\mathrm{~m}, 3 \mathrm{H}$, indane), 2.25 (t, $\left.J=2.4 \mathrm{~Hz}, 1 \mathrm{H}, \mathrm{CH} \equiv \mathrm{C}-\mathrm{CH}_{2}\right), 2.55\left(\mathrm{t}, J=7.3 \mathrm{~Hz}, 2 \mathrm{H}, \mathrm{N}-\mathrm{CH}_{2}-\mathrm{CH}_{2}\right), 2.70-2.82$ (m, 4H, piperazine), 3.29-3.34 (m, 4H, piperazine), 3.51 (dd, $J=5.3,2.4 \mathrm{~Hz}, 2 \mathrm{H}, \mathrm{NH}-\mathrm{CH}_{2}-$ $\mathrm{C} \equiv \mathrm{CH}), 4.02\left(\mathrm{t}, J=6.2 \mathrm{~Hz}, 2 \mathrm{H}, \mathrm{O}-\mathrm{CH}_{2}-\mathrm{CH}_{2}\right), 4.42\left(\mathrm{dd}, J=6.9,5.2 \mathrm{~Hz}, 1 \mathrm{H}, \mathrm{CH}-\mathrm{NH}-\mathrm{CH}_{2}\right), 5.26$ (s, 2H, N-CH2-Ar), 6.56 (dd, $J=2.6,0.9 \mathrm{~Hz}, 1 \mathrm{H}, \mathrm{Ar}-\mathrm{H}), 6.61$ (d, $J=7.4 \mathrm{~Hz}, 1 \mathrm{H}, \mathrm{Ar}-\mathrm{H}), 6.73$ (d, $J=8.3 \mathrm{~Hz}, 1 \mathrm{H}, \mathrm{Ar}-\mathrm{H}), 6.88-6.97$ (m, 3H, Ar-H), 7.04-7.12 (m, 3H, Ar-H), 7.14-7.23 (m,

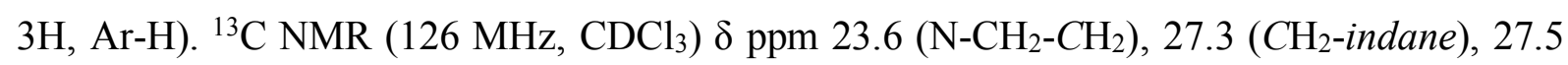
(O- $\left.\mathrm{CH}_{2}-\mathrm{CH}_{2}\right), 33.1\left(\mathrm{CH}_{2}\right.$-indane), $36.2\left(\mathrm{NH}-\mathrm{CH}_{2}-\mathrm{C}\right), 49.7\left(\mathrm{~N}-\mathrm{CH}_{2}-\mathrm{Ar}\right), 51.3$ (piperazine), 53.6 (piperazine), $58.5\left(\mathrm{~N}-\mathrm{CH}_{2}-\mathrm{CH}_{2}\right), 62.4$ (CH-indane), $67.7\left(\mathrm{O}-\mathrm{CH}_{2}-\mathrm{CH}_{2}\right), 71.5\left(\mathrm{CH}_{2}-\mathrm{C} \equiv \mathrm{CH}\right)$, 82.6 $\left(\mathrm{CH}_{2}-\mathrm{C} \equiv \mathrm{CH}\right), 100.8,104.4,106.9,110.2,116.5,122.0,122.8,124.9,126.7,126.8,127.9$, $130.1,131.8,134.8,137.5,139.8,145.9,146.5,155.7$. 


\subsubsection{2.(S)-2-((4-((6-(4-(1-(3-Chlorobenzyl)-1H-indol-4-yl)piperazin-1-yl)hexyl)oxy)benzyl)}

amino)propanamide (41)

Pale yellow oil, $87 \mathrm{mg}$ (isolated yield 64\%) following chromatographic purification over silica gel with $\mathrm{CH}_{2} \mathrm{Cl}_{2} / \mathrm{MeOH}(9 / 1, v / v)$; UPLC/MS purity $97 \%, t_{\mathrm{R}}=4.61, \mathrm{C}_{35} \mathrm{H}_{44} \mathrm{ClN}_{5} \mathrm{O}_{2}, \mathrm{MW}$ 602.22, Monoisotopic Mass 601.32, $[\mathrm{M}+\mathrm{H}]^{+}$602.3. ${ }^{1} \mathrm{H}$ NMR (500 MHz, DMSO- $\left.d_{6}\right) \delta$ ppm 1.08 $\left(\mathrm{d}, J=6.9 \mathrm{~Hz}, 3 \mathrm{H}, \mathrm{NH}-\mathrm{CH}-\mathrm{CH}_{3}\right), 1.28-1.36\left(\mathrm{~m}, 2 \mathrm{H}, \mathrm{N}-\mathrm{CH}_{2}-\mathrm{CH}_{2}-\mathrm{CH}_{2}\right), 1.36-1.42(\mathrm{~m}, 2 \mathrm{H}, \mathrm{O}-$ $\left.\mathrm{CH}_{2}-\mathrm{CH}_{2}-\mathrm{CH}_{2}\right), 1.42-1.49\left(\mathrm{~m}, 2 \mathrm{H}, \mathrm{N}-\mathrm{CH}_{2}-\mathrm{CH}_{2}\right), 1.63-1.71\left(\mathrm{~m}, 2 \mathrm{H}, \mathrm{O}-\mathrm{CH}_{2}-\mathrm{CH}_{2}\right), 2.32(\mathrm{t}$, $J=7.2 \mathrm{~Hz}, 2 \mathrm{H}, \mathrm{N}-\mathrm{CH}_{2}-\mathrm{CH}_{2}$ ), 2.54 (br. s., 4H, piperazine), 2.96 (q, $J=6.9 \mathrm{~Hz}, 1 \mathrm{H}, \mathrm{NH}-\mathrm{CH}-$ $\mathrm{CH}_{3}$ ), 3.07 (br. s., 4H, piperazine), 3.43 (d, $J=13.2 \mathrm{~Hz}, 1 \mathrm{H}, \mathrm{Ar}-\mathrm{CH} H_{1 a}-\mathrm{NH}$ ), 3.56 (d, $J=13.2$ $\left.\mathrm{Hz}, 1 \mathrm{H}, \mathrm{Ar}-\mathrm{CH}_{1 b}-\mathrm{NH}\right), 3.89$ (t, $\left.J=6.6 \mathrm{~Hz}, 2 \mathrm{H}, \mathrm{O}-\mathrm{CH}_{2}-\mathrm{CH}_{2}\right), 5.35$ (s, 2H, N-CH $\left.-\mathrm{Ar}\right), 6.40$ (d, $J=3.4 \mathrm{~Hz}, 1 \mathrm{H}, \mathrm{Ar}-\mathrm{H}), 6.43$ (d, $J=7.5 \mathrm{~Hz}, 1 \mathrm{H}, \mathrm{Ar}-\mathrm{H}), 6.80-6.84\left(\mathrm{~m}, 2 \mathrm{H}, \mathrm{CO}-\mathrm{NH}_{2}\right), 6.91-6.97$ (m, 2H, Ar-H), 6.99-7.03 (m, 1H, Ar-H), 7.07 (d, J=6.9 Hz, 1H, Ar-H), 7.15-7.21 (m, 3H, Ar-H), 7.24-7.31 (m, 3H, Ar-H), 7.39 (d, $J=2.9$ Hz, 1H, Ar-H). ${ }^{13} \mathrm{C}$ NMR (126 MHz, DMSO$\left.d_{6}\right) \delta$ ppm $19.8\left(\mathrm{CH}_{3}-\mathrm{CH}-\mathrm{NH}\right), 26.1\left(\mathrm{~N}-\mathrm{CH}_{2}-\mathrm{CH}_{2}-\mathrm{CH}_{2}\right), 26.8\left(\mathrm{O}-\mathrm{CH}_{2}-\mathrm{CH}_{2}-\mathrm{CH}_{2}\right), 27.3\left(\mathrm{~N}-\mathrm{CH}_{2}-\right.$ $\left.\mathrm{CH}_{2}\right), 29.3\left(\mathrm{O}-\mathrm{CH}_{2}-\mathrm{CH}_{2}\right), 49.0\left(\mathrm{~N}-\mathrm{CH}_{2}-\mathrm{Ar}\right), 51.0\left(\mathrm{~N}-\mathrm{CH}_{2}-\mathrm{CH}_{2}\right), 51.4$ (piperazine), 53.7 (piperazine), $56.9\left(\mathrm{NH}-\mathrm{CH}-\mathrm{CH}_{3}\right), 58.5\left(\mathrm{O}-\mathrm{CH}_{2}-\mathrm{CH}_{2}\right), 67.9\left(\mathrm{Ar}-\mathrm{CH}_{2}-\mathrm{NH}\right), 100.7,104.9,106.6$, 114.6, 121.8, 122.6, 126.2, 127.2, 127.8, 129.7, 131.0, 132.7, 133.7, 137.3, 141.5, 146.1, 158.1, $177.4(\mathrm{C}=\mathrm{O})$.

\subsubsection{3.(S)-2-((4-(4-(4-(1-(Phenylsulfonyl)-1H-indol-4-yl)piperazin-1-yl)butoxy)benzyl)} amino)propanamide (42)

Pale yellow oil, $82 \mathrm{mg}$ (isolated yield 60\%) following chromatographic purification over silica gel with $\mathrm{CH}_{2} \mathrm{Cl}_{2} / \mathrm{MeOH}(9 / 1, v / v)$; UPLC/MS purity $96 \%$, $t_{\mathrm{R}}=4.41, \mathrm{C}_{32} \mathrm{H}_{39} \mathrm{~N}_{5} \mathrm{O}_{4} \mathrm{~S}, \mathrm{MW} 589.76$, Monoisotopic Mass 589.27, $[\mathrm{M}+\mathrm{H}]^{+}$590.4. ${ }^{1} \mathrm{H}$ NMR $\left(500 \mathrm{MHz}, \mathrm{CDCl}_{3}\right) \delta$ ppm $1.35(\mathrm{~d}, J=6.9$ $\left.\mathrm{Hz}, 3 \mathrm{H}, \mathrm{NH}-\mathrm{CH}-\mathrm{CH}_{3}\right), 1.67-1.76\left(\mathrm{~m} ., 2 \mathrm{H}, \mathrm{N}-\mathrm{CH}_{2}-\mathrm{CH}_{2}\right), 1.78-1.86\left(\mathrm{~m}, 2 \mathrm{H}, \mathrm{O}-\mathrm{CH}_{2}-\mathrm{CH}_{2}\right), 2.51$ (t, $J=6.3 \mathrm{~Hz}, 2 \mathrm{H}, \mathrm{N}-\mathrm{CH}_{2}-\mathrm{CH}_{2}$ ), 2.68 (br. s., 4H, piperazine), 3.15 (br. s., 4H, piperazine), 3.22 (q, $\left.J=6.3 \mathrm{~Hz}, 1 \mathrm{H}, \mathrm{NH}-\mathrm{CH}-\mathrm{CH}_{3}\right), 3.63-3.74\left(\mathrm{~m}, 2 \mathrm{H}, \mathrm{Ar}-\mathrm{CH}_{2}-\mathrm{NH}\right), 3.97$ (t, $J=6.0 \mathrm{~Hz}, 2 \mathrm{H}, \mathrm{O}-$ $\mathrm{CH}_{2}-\mathrm{CH}_{2}$ ), 5.59 (br.s., $\left.1 \mathrm{H}, \mathrm{CO}-\mathrm{N} H_{1 a}\right), 6.66$ (d, $\left.J=4.0 \mathrm{~Hz}, 1 \mathrm{H}, \mathrm{Ar}-\mathrm{H}\right), 6.71$ (d, $J=7.4 \mathrm{~Hz}, 1 \mathrm{H}$, Ar-H), 6.82-6.87 (m, 2H, Ar-H), 7.09 (br.s., 1H, CO-NH $H_{l b}$ ), 7.15-7.23 (m, 3H, Ar-H), 7.387.43 (m, 2H, Ar-H), 7.46-7.55 (m, 2H, Ar-H), 7.63 (d, $J=8.0 \mathrm{~Hz}, 1 \mathrm{H}, \mathrm{Ar}-\mathrm{H}), 7.85$ (d, $J=7.4$ $\mathrm{Hz}, 2 \mathrm{H}, \mathrm{Ar}-\mathrm{H}) .{ }^{13} \mathrm{C}$ NMR $\left(126 \mathrm{MHz}, \mathrm{CDCl}_{3}\right) \delta \mathrm{ppm} 19.8\left(\mathrm{CH}_{3}-\mathrm{CH}-\mathrm{NH}\right), 23.4\left(\mathrm{~N}_{-} \mathrm{CH}_{2}-\mathrm{CH}_{2}\right)$, $27.3\left(\mathrm{O}-\mathrm{CH}_{2}-\mathrm{CH}_{2}\right), 29.8$ (piperazine), 51.5 (piperazine), $52.1\left(\mathrm{~N}-\mathrm{CH}_{2}-\mathrm{CH}_{2}\right), 53.5$ (piperazine), $57.7\left(\mathrm{NH}-\mathrm{CH}-\mathrm{CH}_{3}\right), 58.3\left(\mathrm{O}-\mathrm{CH}_{2}-\mathrm{CH}_{2}\right), 67.8\left(\mathrm{Ar}-\mathrm{CH}_{2}-\mathrm{NH}\right), 107.5,108.0,110.9,114.6,124.2$, $124.9,125.6,126.9,129.3,131.6,133.9,136.0,138.3,146.1,158.4,178.2(\mathrm{C}=\mathrm{O})$. 
4.1.10.4.N-(4-((5-(4-(1-(3-Chlorobenzyl)-1H-indol-4-yl)piperazin-1-yl)pentyl)oxy) benzyl)-Nmethylprop-2-yn-1-amine (45)

Pale yellow oil, $99 \mathrm{mg}$ (isolated yield 75\%) following chromatographic purification over silica gel with $\mathrm{CH}_{2} \mathrm{Cl}_{2} / \mathrm{MeOH}(9 / 0.7, v / v)$; UPLC/MS purity $100 \%, t_{\mathrm{R}}=5.73, \mathrm{C}_{35} \mathrm{H}_{41} \mathrm{ClN}_{4} \mathrm{O}$, MW 569.19, Monoisotopic Mass 568.30, $[\mathrm{M}+\mathrm{H}]^{+}$569.4. ${ }^{1} \mathrm{H}$ NMR $\left(500 \mathrm{MHz}, \mathrm{CDCl}_{3}\right) \delta \mathrm{ppm} 1.47-$ $1.56\left(\mathrm{~m}, 2 \mathrm{H}, \mathrm{O}-\mathrm{CH}_{2}-\mathrm{CH}_{2}-\mathrm{CH}_{2}\right), 1.61-1.70\left(\mathrm{~m}, 2 \mathrm{H}, \mathrm{N}-\mathrm{CH}_{2}-\mathrm{CH}_{2}\right), 1.79-1.86$ (m, 2H, O- $\mathrm{CH}_{2}-$ $\left.\mathrm{CH}_{2}\right), 2.23-2.28\left(\mathrm{~m}, 1 \mathrm{H}, \mathrm{CH} \equiv \mathrm{C}-\mathrm{CH}_{2}\right), 2.33\left(\mathrm{~s}, 3 \mathrm{H}, \mathrm{N}-\mathrm{CH}_{3}\right), 2.46-2.54\left(\mathrm{~m}, 2 \mathrm{H}, \mathrm{N}-\mathrm{CH}_{2}-\mathrm{CH}_{2}\right)$, 2.74 (br. s, $4 \mathrm{H}$, piperazine), 3.28 (d, $J=2.3 \mathrm{~Hz}, 2 \mathrm{H}, \mathrm{N}-\mathrm{CH}_{2}-\mathrm{C} \equiv \mathrm{CH}$ ), 3.32 (br. s, $4 \mathrm{H}$, piperazine), 3.50 (s, 2H, CH $\left.3-\mathrm{N}-\mathrm{CH}_{2}-\mathrm{Ar}\right), 3.96$ (t, $J=6.4 \mathrm{~Hz}, 2 \mathrm{H}, \mathrm{O}-\mathrm{CH}_{2}-\mathrm{CH}_{2}$ ), 5.25 (s, 2H, N-CH $-\mathrm{Ar}$ ), $6.56(\mathrm{~d}, J=3.2 \mathrm{~Hz}, 1 \mathrm{H}, \mathrm{Ar}-\mathrm{H}), 6.59-6.62(\mathrm{~m}, 1 \mathrm{H}, \mathrm{Ar}-\mathrm{H}), 6.85$ (d, $J=8.6 \mathrm{~Hz}, 2 \mathrm{H}, \mathrm{Ar}-\mathrm{H}), 6.91$ (dd, $J=10.9,7.2 \mathrm{~Hz}, 2 \mathrm{H}, \mathrm{Ar}-\mathrm{H}), 7.04-7.11$ (m, 3H, Ar-H), 7.16-7.27 (m, 4H, Ar-H). ${ }^{13} \mathrm{C}$ NMR $\left(126 \mathrm{MHz}, \mathrm{CDCl}_{3}\right) \delta$ ppm $24.2\left(\mathrm{~N}_{-}-\mathrm{CH}_{2}-\mathrm{CH}_{2}-\mathrm{CH}_{2}\right), 26.7\left(\mathrm{~N}-\mathrm{CH}_{2}-\mathrm{CH}_{2}\right), 29.3$ (piperazine), 29.8 (piperazine), $30.4\left(\mathrm{O}-\mathrm{CH}_{2}-\mathrm{CH}_{2}\right), 41.8\left(\mathrm{~N}-\mathrm{CH}_{3}\right), 44.7\left(\mathrm{~N}-\mathrm{CH}_{2}-\mathrm{CH}_{2}\right), 49.7\left(\mathrm{~N}-\mathrm{CH}_{2}-\mathrm{Ar}\right), 51.3$ (piperazine), 53.7 (piperazine), $58.8\left(\mathrm{O}-\mathrm{CH}_{2}-\mathrm{CH}_{2}\right), 59.4\left(\mathrm{Ar}-\mathrm{CH}_{2}-\mathrm{N}-\mathrm{CH}_{3}\right), 67.9\left(\mathrm{CH}_{2}-\mathrm{C} \equiv \mathrm{CH}\right)$, $73.4\left(\mathrm{CH}_{2}-\mathrm{C} \equiv \mathrm{CH}\right), 78.7\left(\mathrm{CH}_{2}-\mathrm{C} \equiv \mathrm{CH}\right), 100.8,104.4,106.9,114.4,122.1,122.8,124.9,126.7$, $126.8,127.9,130.1,130.3,130.5,134.8,137.5,139.8,145.9,158.4$.

\subsubsection{N-Methyl-N-(4-(4-(4-(1-(phenylsulfonyl)-1H-indol-4-yl)piperazin-1-yl)butoxy)}

benzyl)prop-2-yn-1-amine (47)

Pale yellow oil, $100 \mathrm{mg}$ (isolated yield 75\%) following chromatographic purification over silica gel with $\mathrm{CH}_{2} \mathrm{Cl}_{2} / \mathrm{MeOH}(9 / 0.7, v / v)$; UPLC/MS purity $97 \%, t_{\mathrm{R}}=4.49, \mathrm{C}_{33} \mathrm{H}_{38} \mathrm{~N}_{4} \mathrm{O}_{3} \mathrm{~S}, \mathrm{MW}$ 570.75, Monoisotopic Mass 570.27, $[\mathrm{M}+\mathrm{H}]^{+}$571.4. ${ }^{1} \mathrm{H}$ NMR $\left(500 \mathrm{MHz}, \mathrm{CDCl}_{3}\right) \delta \mathrm{ppm} 1.67-$ $1.75\left(\mathrm{~m}, 2 \mathrm{H}, \mathrm{N}-\mathrm{CH}_{2}-\mathrm{CH}_{2}\right), 1.79-1.85\left(\mathrm{~m}, 2 \mathrm{H}, \mathrm{O}-\mathrm{CH}_{2}-\mathrm{CH}_{2}\right), 2.25$ (t, $J=2.3 \mathrm{~Hz}, 1 \mathrm{H}, \mathrm{CH} \equiv \mathrm{C}-$ $\mathrm{CH}_{2}$ ), 2.31 (s, 3H, N-CH $), 2.49$ (t, J = 7.4 Hz, 2H, N-CH $-\mathrm{CH}_{2}$ ), 2.58-2.74 (m, 4H, piperazine), $3.15\left(\mathrm{t}, J=4.3 \mathrm{~Hz}, 4 \mathrm{H}\right.$, piperazine), 3.27 (d, $\left.J=2.3 \mathrm{~Hz}, 2 \mathrm{H}, \mathrm{N}-\mathrm{CH}_{2}-\mathrm{C} \equiv \mathrm{CH}\right), 3.49$ (s, 2H, $\mathrm{CH}_{3}-$ $\mathrm{N}-\mathrm{CH}_{2}$-Ar), 3.97 (t, $J=6.3 \mathrm{~Hz}, 2 \mathrm{H}, \mathrm{O}-\mathrm{CH}_{2}-\mathrm{CH}_{2}$ ), 6.67 (dd, J=3.7, 0.9 Hz, 1H, Ar-H), 6.71 (d, $J=7.7 \mathrm{~Hz}, 1 \mathrm{H}, \mathrm{Ar}-\mathrm{H}), 6.82-6.86$ (m, 2H, Ar-H), 7.18-7.26 (m, 3H, Ar-H), 7.37-7.45 (m, 2H, Ar-H), 7.48-7.53 (m, 2H, Ar-H), 7.64 (d, $J=8.3 \mathrm{~Hz}, 1 \mathrm{H}, \mathrm{Ar}-\mathrm{H}), 7.83-7.88$ (m, 2H, Ar-H). ${ }^{13} \mathrm{C}$ NMR $\left(126 \mathrm{MHz}, \mathrm{CDCl}_{3}\right) \delta$ ppm $23.5\left(\mathrm{~N}-\mathrm{CH}_{2}-\mathrm{CH}_{2}\right), 27.4\left(\mathrm{O}-\mathrm{CH}_{2}-\mathrm{CH}_{2}\right), 41.8\left(\mathrm{~N}-\mathrm{CH}_{3}\right), 44.7$ $\left(\mathrm{N}-\mathrm{CH}_{2}-\mathrm{CH}_{2}\right), 51.6$ (piperazine), 53.5 (piperazine), $58.4\left(\mathrm{O}-\mathrm{CH}_{2}-\mathrm{CH}_{2}\right), 59.4\left(\mathrm{Ar}-\mathrm{CH}_{2}-\mathrm{N}-\mathrm{CH}_{3}\right)$, $67.7\left(\mathrm{CH}_{2}-\mathrm{C} \equiv \mathrm{CH}\right), 73.4\left(\mathrm{CH}_{2}-\mathrm{C} \equiv \mathrm{CH}\right), 78.7\left(\mathrm{CH}_{2}-\mathrm{C} \equiv \mathrm{CH}\right), 107.6,107.9,110.9,114.4,124.3$, $124.8,125.6,126.9,129.3,130.4,133.9,136.0,138.3,146.2,158.4$. 


\subsubsection{N-Methyl-N-(4-((5-(4-(1-(phenylsulfonyl)-1H-indol-4-yl)piperazin-1-yl)pentyl)oxy) benzyl)prop-2-yn-1-amine (48)}

Pale yellow oil, $103 \mathrm{mg}$ (isolated yield 78\%) following chromatographic purification over silica gel with $\mathrm{CH}_{2} \mathrm{Cl}_{2} / \mathrm{MeOH}(9 / 0.7, v / v)$; UPLC/MS purity $100 \%, t_{\mathrm{R}}=4.61, \mathrm{C}_{33} \mathrm{H}_{38} \mathrm{~N}_{4} \mathrm{O}_{3} \mathrm{~S}$, MW 584.78, Monoisotopic Mass 584.28, $[\mathrm{M}+\mathrm{H}]^{+}$585.5. ${ }^{1} \mathrm{H} \mathrm{NMR}\left(500 \mathrm{MHz}, \mathrm{CDCl}_{3}\right) \delta \mathrm{ppm}$ 1.48-1.56 (m, 2H, O-CH $\left.-\mathrm{CH}_{2}-\mathrm{CH}_{2}\right), 1.60-1.67$ (m, 2H, N-CH$\left.-\mathrm{CH}_{2}\right), 1.79-1.86(\mathrm{~m}, 2 \mathrm{H}, \mathrm{O}-$ $\left.\mathrm{CH}_{2}-\mathrm{CH}_{2}\right), 2.28$ (t, $\left.J=2.6 \mathrm{~Hz}, 1 \mathrm{H}, \mathrm{CH} \equiv \mathrm{C}-\mathrm{CH}_{2}\right), 2.33\left(\mathrm{~s}, 3 \mathrm{H}, \mathrm{N}-\mathrm{CH}_{3}\right), 2.47$ (t, $J=7.4 \mathrm{~Hz}, 2 \mathrm{H}$, $\mathrm{N}-\mathrm{CH}_{2}-\mathrm{CH}_{2}$ ), 2.68 (br. s., 4H, piperazine), 3.18 (t, $J=4.6 \mathrm{~Hz}, 4 \mathrm{H}$, piperazine), 3.29 (d, $J=2.3$ $\mathrm{Hz}, 2 \mathrm{H}, \mathrm{N}-\mathrm{CH}_{2}-\mathrm{C} \equiv \mathrm{CH}$ ), 3.51 (s, 2H, $\mathrm{CH}_{3}-\mathrm{N}-\mathrm{CH}_{2}-\mathrm{Ar}$ ), 3.96 (t, $\mathrm{J}=6.3 \mathrm{~Hz}, 2 \mathrm{H}, \mathrm{O}-\mathrm{CH}_{2}-\mathrm{CH}_{2}$ ), 6.68-6.70 (m, 1H, Ar-H), 6.73 (d, J=7.5 Hz, 1H, Ar-H), 6.83-6.87 (m, 2H, Ar-H), 7.20-7.26 (m, 3H, Ar-H), 7.40-7.44 (m, 2H, Ar-H), 7.50-7.53 (m, 1H, Ar-H), 7.53 (d, J=3.4 Hz, 1H, Ar-H), 7.66 (d, $J=8.6 \mathrm{~Hz}, 1 \mathrm{H}, \mathrm{Ar}-\mathrm{H}), 7.86-7.87$ (m, 1H, Ar-H), $7.88-7.89$ (m, 1H, Ar-H). ${ }^{13} \mathrm{C}$ NMR $\left(126 \mathrm{MHz}, \mathrm{CDCl}_{3}\right) \delta$ ppm $24.2\left(\mathrm{~N}-\mathrm{CH}_{2}-\mathrm{CH}_{2}-\mathrm{CH}_{2}\right), 26.6\left(\mathrm{~N}-\mathrm{CH}_{2}-\mathrm{CH}_{2}\right), 29.3\left(\mathrm{O}_{-} \mathrm{CH}_{2}-\right.$ $\left.\mathrm{CH}_{2}\right), 41.7\left(\mathrm{~N}-\mathrm{CH}_{3}\right), 44.7\left(\mathrm{~N}-\mathrm{CH}_{2}-\mathrm{CH}_{2}\right), 51.5$ (piperazine), 53.5 (piperazine), $58.7\left(\mathrm{O}-\mathrm{CH}_{2}-\right.$ $\left.\mathrm{CH}_{2}\right), 59.4\left(\mathrm{Ar}-\mathrm{CH}_{2}-\mathrm{N}-\mathrm{CH}_{3}\right), 67.8\left(\mathrm{CH}_{2}-\mathrm{C} \equiv \mathrm{CH}\right), 73.4\left(\mathrm{CH}_{2}-\mathrm{C} \equiv \mathrm{CH}\right), 78.7\left(\mathrm{CH}_{2}-\mathrm{C} \equiv \mathrm{CH}\right), 107.6$, $108.0,110.9,114.4,124.3,124.9,125.6,126.9,129.3,130.3,130.5,133.9,136.0,138.3,146.2$, 158.4. Anal. calcd for dihydrochloride dihydrate salt $\mathrm{C}_{33} \mathrm{H}_{38} \mathrm{~N}_{4} \mathrm{O}_{3} \mathrm{~S} \cdot 2 \mathrm{HCl} \cdot 2 \mathrm{H}_{2} \mathrm{O}: \mathrm{C}: 58.87, \mathrm{H}$ : 6.68, N: 8.08, S: 4.62; Found C: 59.03, H: 6.44, N: 7.72, S: 4.39. M.p. for $\mathrm{C}_{33} \mathrm{H}_{38} \mathrm{~N}_{4} \mathrm{O}_{3} \mathrm{~S} \cdot 2 \mathrm{HCl} \cdot 2 \mathrm{H}_{2} \mathrm{O}: 215.1-219.3^{\circ} \mathrm{C}$.

\subsection{In silico simulations}

\subsubsection{Molecular docking}

The 5- $\mathrm{HT}_{6} \mathrm{R}$ homology models were obtained according to the procedure described before on the $\beta_{2}$ receptor template and successfully used in our earlier studies of different groups of 5 - $\mathrm{HT}_{6} \mathrm{R}$ ligands simulations. ${ }^{48,49}$ The structure of monoamine oxidases B (PDB code $\left.2 \mathrm{C} 65\right)^{38}$ in complex with irreversible inhibitor rasagilline analog (4-(N-methyl-N-ethyl-carbamoyloxy)N-methyl-N-propargyl-1(R)-aminoindan) was fetched from the Protein Data Bank. The structures of the 5- $\mathrm{HT}_{6}$ receptor and MAO-B enzyme were optimized using the induced-fit docking (IFD) procedure from Schrödinger Suite. The IFD combines flexible ligand docking with target structure prediction and side chain refinement. The structure of $\mathbf{4 8}$ was used as input to IFD. Centroid of the grid box was anchored on D3.32 and I199 in 5-HT6 and MAO-B, respectively. Due to the size of the input ligand, it allowed on residue refinement within $12 \AA$ and $33 \AA$ A of ligand poses for 5-HT 6 and MAO-B, respectively. The Extended Sampling Protocol was used, which generates up to 80 poses per ligand by automated docking. All obtained L-R 
complexes were inspected visually to select those that displayed the closest compliance with the common binding mode for studied protein targets. Final validation of the selected conformations was performed by docking (Glide SP mode) the designed library, retaining only those with a coherent binding mode. ${ }^{50}$ The 3-dimensional structures of the ligands were obtained using LigPrep v3.6, ${ }^{51}$ and the appropriate ionization states at $\mathrm{pH}=7.4 \pm 1.0$ were assigned using Epik v3.4. ${ }^{52}$

\subsection{2. $Q M / M M$ Optimization}

The L-R complexes selected in IFD procedure were next optimized using QM/MM approach using QSite. The QM region contained ligand and amino acid side chain directly interacting with the ligand was described by a combination of DFT hybrid functional B3LYP and LACVP* basis set, while the rest of the system was optimized using OPLS2005 force field.

\subsubsection{Covalent docking}

The CovDock workflow ${ }^{53}$ from Schrodinger Suite was used for pose prediction and scoring of covalently bound ligands to a flavin adenine dinucleotide cofactor (FAD) presence in catalytic site of MAO-B enzyme. The reaction between FAD and propargyl group was not pre-defined in CovDock library, thus we used custom reaction editor to describe the reaction based on the mechanism proposed by Tandarić et al. ${ }^{39}$ At first, we defined in SMARTS language the fragments of the ligand $[\mathrm{C} \# \mathrm{CC}[\mathrm{N}, \mathrm{n}]]$ and $\mathrm{FAD}[[\mathrm{nH}] \mathrm{c}(=\mathrm{O}) \mathrm{cNc}]$ between which the reaction occurs. The grid center was set to I199, assuming its size to $33 \AA$. The rest setting was used as default.

\subsection{In vitro pharmacological evaluation}

\subsubsection{Radioligand binding assays}

All experiments were carried out according to the previously published procedures. ${ }^{54-56}$ HEK293 cells stably expressing human 5- $\mathrm{HT}_{1 \mathrm{~A}}, 5-\mathrm{HT}_{6}, 5-\mathrm{HT}_{7 \mathrm{~b}}$ and $\mathrm{D}_{2 \mathrm{~L}}$ receptors (prepared with the use of Lipofectamine 2000) or CHO-K1 cells with plasmid containing the sequence coding for the human serotonin $5-\mathrm{HT}_{2 \mathrm{~A}}$ receptor (Perkin Elmer) were maintained at $37^{\circ} \mathrm{C}$ in a humidified atmosphere containing 5\% $\mathrm{CO}_{2}$ and grown in Dulbecco's Modified Eagle's Medium containing $10 \%$ dialyzed fetal bovine serum and $500 \mu \mathrm{g} / \mathrm{ml}$ G418 sulfate. For membrane preparation, cells were cultured in $150 \mathrm{~cm}^{2}$ flasks, grown to $90 \%$ confluence, washed twice 
with pre-warmed to $37{ }^{\circ} \mathrm{C}$ phosphate buffered saline (PBS) and centrifuged $(200 \times \mathrm{g})$ in PBS containing $0.1 \mathrm{mM}$ EDTA and $1 \mathrm{mM}$ dithiothreitol. Prior to membrane preparation, pellets were stored at $-80{ }^{\circ} \mathrm{C}$.

Cell pellets were thawed and homogenized in 10 volumes of assay buffer using an Ultra Turrax tissue homogenizer and centrifuged twice at $35,000 \times \mathrm{g}$ for $15 \mathrm{~min}$ at $4{ }^{\circ} \mathrm{C}$, with incubation for 15 min at $37^{\circ} \mathrm{C}$ between the centrifugations. The composition of the assay buffers was experimentally selected to achieve the maximum signal window (more details in SI). All assays were carried out in a total volume of $200 \mu \mathrm{L}$ in 96 -well plates for $1 \mathrm{~h}$ at $37^{\circ} \mathrm{C}$, except $5-\mathrm{HT}_{1 \mathrm{~A}} \mathrm{R}$ and $5-\mathrm{HT}_{2 \mathrm{~A}} \mathrm{R}$ which were incubated at room temperature and $27{ }^{\circ} \mathrm{C}$, respectively. The process of equilibration was terminated by rapid filtration through Unifilter plates with a 96-well cell harvester and radioactivity retained on the filters was quantified on a Microbeta plate reader (PerkinElmer, USA). For displacement studies the assay samples contained as radioligands (PerkinElmer, USA): $2.5 \mathrm{nM} \mathrm{[{ } ^ { 3 } \mathrm { H } ] - 8 - O H - D P A T}(135.2 \mathrm{Ci} / \mathrm{mmol})$ for $5-\mathrm{HT}_{1 \mathrm{~A}} \mathrm{R} ; 1 \mathrm{nM}\left[{ }^{3} \mathrm{H}\right]-$ ketanserin $(53.4 \mathrm{Ci} / \mathrm{mmol})$ for $5-\mathrm{HT}_{2 \mathrm{~A}} \mathrm{R} ; 2 \mathrm{nM}\left[{ }^{3} \mathrm{H}\right]-\mathrm{LSD}(83.6 \mathrm{Ci} / \mathrm{mmol})$ for $5-\mathrm{HT}_{6} \mathrm{R} ; 0.8 \mathrm{nM}$ $\left[{ }^{3} \mathrm{H}\right]-5-\mathrm{CT}(39.2 \mathrm{Ci} / \mathrm{mmol})$ for $5-\mathrm{HT}_{7} \mathrm{R}$ or $2.5 \mathrm{nM}\left[{ }^{3} \mathrm{H}\right]$-raclopride $(76.0 \mathrm{Ci} / \mathrm{mmol})$ for $\mathrm{D}_{2 \mathrm{~L}} \mathrm{R}$. Non-specific binding was defined in the presence of $10 \mu \mathrm{M}$ of 5 -HT in $5-\mathrm{HT}_{1 \mathrm{~A}} \mathrm{R}$ and $5-\mathrm{HT}_{7} \mathrm{R}$ binding experiments, whereas $20 \mu \mathrm{M}$ of mianserin, $10 \mu \mathrm{M}$ of methiothepine or $10 \mu \mathrm{M}$ of haloperidol were used in 5- $\mathrm{HT}_{2 \mathrm{~A}} \mathrm{R}, 5-\mathrm{HT}_{6} \mathrm{R}$ and $\mathrm{D}_{2 \mathrm{~L}}$ assays, respectively. Each compound was tested in triplicate at 7 concentrations $\left(10^{-10}-10^{-4} \mathrm{M}\right)$. The inhibition constants $\left(K_{\mathrm{i}}\right)$ were calculated from the Cheng-Prusoff equation. ${ }^{57}$

Additionally, the affinity of compound 48 and $\alpha_{1}$ and $\beta_{1}$-adrenergic receptors, histaminic $\mathrm{H}_{1}$ and muscarinic $\mathrm{M}_{1}$ receptors were evaluated at Eurofins. The results were expressed as the \% inhibition of the control binding according to experimental protocols described online at https://www.eurofins.com/.

\subsubsection{Monoamine Oxidase Assays}

Inhibition activity of evaluated compounds was measured using human recombinant MAO-B and MAO-A (Sigma Aldrich M7441 and M7316) in the fluorometric method for detecting monoamine oxidase activity. The assay was carried out in 96-well plate. $2 \mu \mathrm{L}$ of appropriate concentration of tested compounds in DMSO were added to wells that contained $98 \mu \mathrm{L}$ of enzyme dilution $(0.53 \mathrm{U} / \mathrm{ml})$ in phosphate buffer $(50 \mathrm{mM}$, pH 7.4). After the 30 minutes of preincubation in room temperature $50 \mu \mathrm{L}$ of the solution of $800 \mu \mathrm{M}$ 10-Acetyl-3,7dihydroxyphenoxazine (Cayman Chemical Company 10010469) and $4 \mathrm{U} / \mathrm{mL}$ horse radish 
peroxidase (HRP, Sigma Aldrich P6782) was added and enzymatic reaction was started by addition of $50 \mu \mathrm{L}$ of $800 \mu \mathrm{M}$ p-tyramine (Alfa Aesar A12220) solution. The signal was measured after $1 \mathrm{~h}$ (excitation at $570 \mathrm{~nm}$ and emission at $585 \mathrm{~nm}$ ) using EnSpire ${ }^{\circledR}$ multimode plate reader (Perkin Elmer, Inc.). Rasagiline $(1 \mu \mathrm{M})$ or clorgyline $(1 \mu \mathrm{M})$ were tested as reference compounds for MAO-B and MAO-A inhibitions, respectively. ${ }_{58,59}$

\subsubsection{Reversibility studies}

To investigate reversibility of MAO-B inhibition compound 48, rasagiline and safinamide were tested in concentration corresponding to their $\mathrm{IC}_{80}$ values. Experiment was carried out in 96well plate divided into two parts. In the first portion $h \mathrm{MAO}-\mathrm{B}$ was incubated with inhibitors for 30 minutes. In the second portion of inhibitors were added to $h \mathrm{MAO}-\mathrm{B}$ directly before the next step. Then $10 \mu \mathrm{M}$ p-tyramine and the solution of $800 \mu \mathrm{M}$ 10-acetyl-3,7-dihydroxyphenoxazine and $4 \mathrm{U} / \mathrm{mL}$ HRP were added to both parts of the plate. Fluorescence signal had been measured in the microplate reader for 22 minutes then the concentration of p-tyramine was increased to $1 \mathrm{mM}$. After addition of p-tyramine fluorescence was measured every 5 minutes for 5 hours. ${ }^{59}$

\subsubsection{Determination of cAMP production in $1321 N 1$ cells}

The properties of compound 48 to inhibit cAMP production induced by 5-CT (1000 nM), a 5$\mathrm{HT}_{6} \mathrm{R}$ agonist, was evaluated. Compounds were tested in triplicate at 8 concentrations $\left(10^{-11}\right.$ $\left.10^{-4} \mathrm{M}\right)$. The level of cAMP was measured using frozen recombinant $1321 \mathrm{~N} 1$ cells expressing the Human Serotonin 5- $\mathrm{HT}_{6} \mathrm{R}$ (PerkinElmer). Total cAMP was measured using the LANCE cAMP detection kit (PerkinElmer), according to the manufacturer's recommendations. For quantification of cAMP levels, 2000 cells/well $(5 \mu \mathrm{L})$ were incubated with mixture of compounds $(5 \mu \mathrm{L})$ for $30 \mathrm{~min}$ at room temperature in 384-well white opaque microtiter plate. After incubation, the reaction was stopped and cells were lysed by the addition of $10 \mu \mathrm{L}$ of working solution ( $5 \mu \mathrm{L}$ Eu-cAMP and $5 \mu \mathrm{L}$ ULight-anti-cAMP) for $1 \mathrm{~h}$ at room temperature. Time-resolved fluorescence resonance energy transfer (TR-FRET) was detected by an Infinite M1000 Pro (Tecan) using instrument settings from LANCE cAMP detection kit manual. $K_{\mathrm{b}}$ values were calculated from Cheng-Prusoff equation specific for the analysis of functional inhibition curves: $K_{\mathrm{b}}=\mathrm{IC}_{50} /\left(1+\mathrm{A} / \mathrm{EC}_{50}\right)$ where A represents agonist concentration, $\mathrm{IC}_{50}$ the 
concentration of antagonist producing a 50\% reduction in the response to agonist, and $\mathrm{EC}_{50}$ the agonist concentration which causes a half of the maximal response. ${ }^{57}$

\subsubsection{Determination of cAMP production in NG108-15 cells}

NG108-15 cells were grown in Dulbecco's modified Eagle's medium (DMEM) supplemented with $10 \%$ dialyzed fetal calf serum, $2 \%$ hypoxanthine/aminopterin/thymidine (Life technologies), and antibiotics. cAMP measurement was performed in cells transiently expressing 5- $\mathrm{HT}_{6} \mathrm{R}$ using the bioluminescence resonance energy transfer (BRET) sensor for cAMP, CAMYEL (cAMP sensor using YFP-Epac-RLuc) ${ }^{60}$ NG108-15 cells were cotransfected in suspension with $5-\mathrm{HT}_{6} \mathrm{R}(0.5 \mu \mathrm{g}$ DNA/million cells) and CAMYEL constructs (1 $\mu \mathrm{g}$ DNA/million cells), using Lipofectamine 2000, according to the manufacturer's protocol, and plated in white 96-well plates (Greiner), at a density of 50,000 cells per well. Twenty-four $\mathrm{h}$ after transfection, cells were washed with PBS containing calcium and magnesium. To test the inverse agonist properties of compound $\mathbf{4 8}$ and intepirdine, cells were treated with vehicle or with the tested compound at incremental concentrations of these compounds (from $0.1 \mathrm{nM}$ to $10 \mu \mathrm{M}$ ). Coelanterazine $\mathrm{H}$ (Molecular Probes) was added at a final concentration of $5 \mu \mathrm{M}$, and left at room temperature for 5 min. BRET was measured using a Mithras LB 940 plate reader (Berthold Technologies). Expression of 5-HT 6 R in NG108-15 cells induced a strong decrease in CAMYEL BRET signal, compared with cells transfected with an empty vector instead of the plasmid encoding the $5-\mathrm{HT}_{6} \mathrm{R}$. This decrease in CAMYEL BRET signal was thus used as an index of 5- $\mathrm{HT}_{6} \mathrm{R}$ constitutive activity at Gs signaling.

\subsection{Assessment of preliminary ADME properties}

\subsubsection{PAMPA - Parallel artificial membrane permeability assay}

Parallel artificial membrane permeability assay (PAMPA) was performed using Corning ${ }^{\circledR}$ Gentest $^{\mathrm{TM}}$ Pre-coated PAMPA Plate System, according to the manufacturer's instructions. Compound $48(100 \mu \mathrm{M})$ was incubated on plates in phosphate-buffer saline ( $\mathrm{pH} 7.4)$ for $5 \mathrm{~h}$ at room temperature. Concentrations of $\mathbf{4 8}$ in donor and acceptor solutions were determined using UPLC-MS with the internal standard based on pentoxifylline method. Membrane permeability expressed as $\log P$ e was calculated as follows: 


$$
\log P e=\log \left(\frac{-\ln \left[1-C_{A} / \frac{C_{D} \times V_{D}+C_{A} \times V_{A}}{V_{D}+V_{A}}\right]}{A \times\left(\frac{1}{V_{D}}+\frac{1}{V_{A}}\right) \times t}\right)
$$

where CD and CA are the final concentrations after incubation and VD, VA - volumes of the donor and the acceptor solutions $(0.3 \mathrm{ml}, 0.2 \mathrm{ml})$, respectively. $\boldsymbol{A}$ - membrane surface area $(0.3 \mathrm{~cm} 2), \mathrm{t}$ - incubation time (18 $000 \mathrm{~s})$. Two reference standards were used in the study verapamil $(\mathrm{Pe}=1.85 * 10-5 \mathrm{~cm} / \mathrm{sec})-$ a well permeable drug and doxorubicin $(\mathrm{Pe}=\mathrm{ND}$, not detected in acceptor compartment) - no membrane penetration properties.

\subsubsection{In vitro metabolic stability studies}

Metabolic stability of tested compound was analyzed using incubation systems, composed of: tested compound $(10 \mu \mathrm{M})$, rat liver microsomes (RLMs, microsomes from rat male liver, pooled; $0.4 \mathrm{mg} / \mathrm{mL}$; Sigma Aldrich), NADPH-regenerating system (NADP+, glucose-6phosphate and glucose-6-phosphate dehydrogenase in $100 \mathrm{mM}$ potassium buffer, $\mathrm{pH}$ 7.4; all from Sigma Aldrich) and potassium buffer, $\mathrm{pH}$ 7.4. Stock solution of tested compounds was prepared in methanol (the final methanol concentration in incubation mixture does not exceed 0,1\%). Firstly, all samples contained incubation mixture (without NADPH-regenerating system) were pre-incubated in thermoblock at $37^{\circ} \mathrm{C}$, for $10 \mathrm{~min}$. Then reaction was initiated by the addition of NADPH-regenerating system. In control samples NADPH-regenerating system was replaced with potassium buffer. Probes were incubated for 30 and $60 \mathrm{~min}$ at $37^{\circ} \mathrm{C}$. After addition of internal standard (pentoxifylline, $10 \mu \mathrm{M}$ ) biotransformation process was stopped by addition of perchloric acid. Next, samples were centrifuge and supernatants were analyzed using UPLC/MS (Waters Corporation, Milford, MA). All experiments were run in duplicates. Half-life time was evaluated using non-linear regression model using Graph Pad Prism software and intristinic clearence was calculated from the equation $\mathrm{Cl}_{\text {int }}=$ (volume of incubation $[\mu 1] /$ protein in the incubation $[\mathrm{mg}]) 0,693 / \mathrm{t}_{1 / 2} .^{61}$

\subsubsection{Preliminary in vivo pharmacokinetics experiments \\ 4.4.3.1. Instrumentation and operating conditions}

The LC/ESI-MS/MS experiments were performed on an ABSciex (Concord, Ontario, Canada) API 3200 triple quadrupole mass spectrometer equipped with an electrospray (ESI) ionization interface. This instrument was coupled to Shimadzu (Shimadzu, Japan) LC system. Data 
acquisition and processing were accomplished using ABSciex Analyst 1.5.2 data collection and integration software.

\subsubsection{Chromatographic and Mass spectrometric conditions}

Acclaim Polar Advantage II (3.0 mm x 74 mm, $3 \mu \mathrm{m}, 120$ A, Dionex, USA) analytical column was used for compound separation. The temperatures of the column thermostat and the autosampler were set at $40^{\circ} \mathrm{C}$ and $10^{\circ} \mathrm{C}$, respectively. The mobile phase consisted of a mixture of acetonitrile with addition of $0.1 \%$ formic acid (solvent $\mathrm{A}$ ) and water with addition of $0.1 \%$ formic acid (solvent B) and was set at a flow rate of $0.4 \mathrm{~mL} / \mathrm{min}$. Starting amount of solvent A is $10 \%$, isocratic elution from 0 to $5 \mathrm{~min}$, and then gradient up to $90 \%$ of solvent $\mathrm{A}$, and maintained to $10 \mathrm{~min}$, and then gradient down to $10 \%$ of solvent $\mathrm{A}$, and maintained to $15 \mathrm{~min}$. To find the optimal parameters of ion path and ion source for studied compound the quantitative optimization was done by direct infusion of the molecule at a concentration of $1 \mu \mathrm{g} / \mathrm{mL}$, and at a flow rate of $10 \mu \mathrm{L} / \mathrm{min}$ using a Hamilton syringe pump (Hamilton, Reno, Nevada). The ion source parameters were as follows: ion spray voltage: $4500 \mathrm{~V}$; nebulizer gas (gas 1): 20 psi; turbo gas (gas 2): 20 psi; temperature of the heated nebulizer: $400^{\circ} \mathrm{C}$; curtain gas: 40 psi; collision gas: 6 psi. Mass spectra were acquired by SRM with precursor/predominant product ion transitions for the analyte. The mass spectral Q1 $\rightarrow \mathrm{Q} 3$ transitions monitored for compound 48 and for IS were $\mathrm{m} / \mathrm{z} 585.1 \rightarrow 516.2$ and $\mathrm{m} / \mathrm{z} 305 \rightarrow 248$, respectively. The peak widths of precursor and product ions were set to 0.7 full width half-height. Quantification was done via peak area ratio.

\subsubsection{Sample pretreatment}

The plasma and brain sample pretreatment procedure involved acetonitrile precipitation. A 5 $\mu \mathrm{L}$ aliquot of the internal standard (IS, PH003437, Merck, Darmstadt, Germany). working solution $(5 \mu \mathrm{g} / \mathrm{mL})$ was added to $100 \mu \mathrm{L}$ of the collected rat plasma sample, which was then vortex-mixed for 10 seconds. Thereafter, $200 \mu \mathrm{L}$ of acetonitrile was added, vortexed during 20 min, and then centrifuged (10 $000 \mathrm{rpm}, 10 \mathrm{~min})$. The supernatant $(200 \mu \mathrm{L})$ was then transferred to insert placed in an autosampler vial, and a $20 \mu \mathrm{L}$ volume of this was injected onto the $\mathrm{LC}$ column. Brain samples were thawed before use, and whole brain were weighted and placed in a glass mortar and pestle tissue grinder, and homogenized with an appropriate amount of phosphate buffer ( $\mathrm{pH} 7.4$ ) in 1:2.5 ratio. Afterward, $100 \mu \mathrm{L}$ of tissue homogenates were transferred to new Eppendorf tubes and spiked with $5 \mu \mathrm{L}$ of the internal standard working 
solution. All samples were stored on ice during the preparation process and followed by procedures similar to those described above.

\subsubsection{Animals}

A group of 32 adult male rats (Wistar, 200 - $220 \mathrm{~g}$ ) were used in the experiment. The animals were purchased from the Animal House at the Faculty of Pharmacy, Jagiellonian University Medical College, Krakow, Poland. During the habituation period the groups of 4 rats were kept in a plastic cage at a controlled room temperature $\left(22 \pm 2^{\circ} \mathrm{C}\right)$, humidity $(55 \pm 10 \%)$, full spectrum cold white light (350-400 lx), on $12 \mathrm{hr}$ light/12 dark cycles (the lights on at 7:00 a.m., and off at 19:00 p.m.), and had free access to standard laboratory pellet and tap water. For pharmacokinetic study compound $\mathbf{4 8}$ dissolved in saline were administered by intragastric gavage at a dose of $3 \mathrm{mg} / \mathrm{kg}$. Blood samples were collected at $0 \mathrm{~min}$ (predose), $5 \mathrm{~min}, 15 \mathrm{~min}$, $30 \mathrm{~min}, 60 \mathrm{~min}, 120 \mathrm{~min}, 240 \mathrm{~min}$ and $480 \mathrm{~min}$ after compound administration. The blood and brain samples were collected under general anesthesia induced by i.p. injection of $50 \mathrm{mg} / \mathrm{kg}$ ketamine plus $8 \mathrm{mg} / \mathrm{kg}$ xylazine. The blood samples were taken into heparinized tubes, immediately centrifuged at 1000xg for $10 \mathrm{~min}$, and plasma was collected. The plasma and brain samples were immediately frozen at $-80^{\circ} \mathrm{C}$. All experimental procedures were carried out in accordance with EU Directive 2010/63/EU and approved by the I Local Ethics Committee for Experiments on Animals of the Jagiellonian University in Krakow, Poland.

\subsection{Assessment of glioprotecting properties}

\subsubsection{Cell culture}

Astrocytes (C8-D1A cells) were cultured in $25 \mathrm{~cm}^{2}$ flask with DMEM supplemented with $10 \% \mathrm{FBS}$ at $37{ }^{\circ} \mathrm{C}$, in a humidified atmosphere with $5 \% \mathrm{CO}_{2}$ until the cells reached $80-90 \%$ confluence. Cells were harvested and seeded in 96-well plates at a density of $1 \times 10^{4}$ cells per well. They were pre-incubated with tested compounds analyzed compounds for 12 hours, then 6-OHDA $(25 \mu \mathrm{M})$ was added for next 24 hours. The ability of compounds to prevent 6-OHDAinduced cytotoxicity was assessed by using the MTT and LDH assays.

\subsubsection{MTT assay}

Cell viability was estimated by using the MTT assay, which assesses the ability mitochondrial dehydrogenases to reduce tetrazolium salts into a colored formazan compound. ${ }^{62}$ At the end of the incubation period, $10 \mu \mathrm{L}$ of MTT $(5 \mathrm{mg} / \mathrm{mL})$ were added to each well. After $4 \mathrm{~h}$, formazan crystals were solubilized with DMSO and optical density was measured at 570 
nm by using a SpectraMax iD3 Multi-Mode Microplate Reader (Molecular Devices). Each experiment was performed in triplicate and repeated three times.

\subsubsection{LDH assay}

Cells were seeded at density $3 \times 10^{4}$ cells/per well in 96 well plates. After $24 \mathrm{~h}$ selegiline, intepirdine, and compound 48 were added to final concentrations of $0,25 \mu \mathrm{M}$. After $24 \mathrm{~h}$ preincubation, 6-OHDA $(25 \mu \mathrm{M})$ was added to the cultures for an additional 24-h period to induce astrocyte injury. Then, plates were centrifuged ( $200 \mathrm{x} \mathrm{g}, 2 \mathrm{~min}$ ) and $50 \mu \mathrm{L}$ of the supernatant were transferred into the corresponding 96-well plate. Subsequently, $50 \mu \mathrm{L}$ of LDH-reaction mixture prepared according to the manufacturer's instructions (Invitrogen) were added to each well. Incubation was conducted in darkness for $30 \mathrm{~min}$ at room temperature. Next, stop solution was added and absorbance was measured at $490 \mathrm{~nm}$ (A490) using a plate reader (Spectra Max iD3, Molecular Devices). Cytotoxicity was determined as follows: cytotoxicity $(\%)=[$ (compound LDH activity - spontaneous LDH activity)/(maximum LDH activity spontaneous LDH activity)] $\times 100$. The maximum LDH activity was prepared by treating cells with lysis buffer (control +). The medium used in the LDH assay contained 1\% FBS. Three independent experiments were performed for each condition.

\subsection{In vivo pharmacological evaluation}

The experiments were performed according to the previously reported procedures ${ }^{63,64}$ and were conducted in accordance with the NIH Guide for the Care and Use of Laboratory Animals and were approved by the Ethics Committee for Animal Experiments, Institute of Pharmacology. Male Sprague-Dawley rats (Charles River, Germany) weighing $\sim 250 \mathrm{~g}$ at the arrival were housed in the standard laboratory cages, under standard colony $\mathrm{A} / \mathrm{C}$ controlled conditions: room temperature $21 \pm 2{ }^{\circ} \mathrm{C}$, humidity (40-50\%), 12-hr light/dark cycle (lights on: 06:00) with ad libitum access to food and water. Rats were allowed to acclimatize for at least 7 days before the start of the experimental procedure. During this week animals were handled for at least 3 times. Behavioral testing was carried out during the light phase of the light/dark cycle. At least $1 \mathrm{~h}$ before the start of the experiment, rats were transferred to the experimental room for acclimation. Rats were tested in a dimly lit (25 1x) "open field" apparatus made of a dull gray plastic $(66 \times 56 \times 30 \mathrm{~cm})$. After each measurement, the floor was cleaned and dried.

\subsubsection{Drug Treatment}


Scopolamine hydrobromide used to attenuate learning, was purchase from Sigma Aldrich (Germany). Scopolamine and tested compound $\mathbf{4 8}$ were solubilized in distilled water and then administered at the dose of $1.25 \mathrm{mg} / \mathrm{kg}$ (i.p.) and $1-3 \mathrm{mg} / \mathrm{kg}$ (p.o.) 30 and $120 \mathrm{~min}$ before familiarization phase (T1), respectively.

\subsubsection{Experimental Procedure}

Procedure consisted of habituation to the arena (without any objects) for $5 \mathrm{~min}, 24$ hours before the test and test session comprised of two trials separated by an inter trial interval (ITI). For scopolamine (SCOP)-induced memory impairment paradigm, 1 hour ITI was chosen. During the first trial (familiarization, T1) two identical objects (A1 and A2) were presented in opposite corners, approximately $10 \mathrm{~cm}$ from the walls of the open field. In the second trial (recognition, $\mathrm{T} 2)$ one of the objects was replaced by a novel one $(\mathrm{A}=$ familiar and $\mathrm{B}=$ novel $)$. Both trials lasted $3 \mathrm{~min}$ and animals were returned to their home cage after T1. The objects used were the glass beakers filled with the gravel and the plastic bottles filled with the sand. The heights of the objects were comparable $(\sim 12 \mathrm{~cm})$ and the objects were heavy enough not to be displaced by the animals. The sequence of presentations and the location of the objects was randomly assigned to each rat. The animals explored the objects by looking, licking, sniffing or touching the object while sniffing, but not when leaning against, standing or sitting on the object. Any rat spending less than $5 \mathrm{~s}$ exploring the two objects within 3 min of T1 or T2 was eliminated from the study. Exploration time of the objects and the distance travelled were measured using the Any-maze ${ }^{\circledR}$ video tracking system. Based on exploration time $(\mathrm{E})$ of two objects during $\mathrm{T} 2$, discrimination index (DI) was calculated according to the formula: $\mathrm{DI}=(\mathrm{EB}-\mathrm{EA}) /(\mathrm{EA}+\mathrm{AB})$.

\section{Acknowledgements}

The authors acknowledge the financial support from the National Science Centre, Poland (grant no. 2016/21/B/NZ7/01742). SCD and PM were supported by grants from CNRS, INSERM, Montpellier University of Excellence (iSITE MUSE), the French Foundation for Medical Research (FRM) and ANR (ANR-17-CE16-0013-01 and ANR-17-CE16-0010-01).

\section{Supporting Information Available}


Supporting information contains characterization data for all intermediates and final compounds excluded from the main manuscript; MS, ${ }^{1} \mathrm{H}-\mathrm{NMR}$ and ${ }^{13} \mathrm{C}-\mathrm{NMR}$ spectra for selected final compounds. This material is available free of charge via the Internet.

\section{References:}

(1) De Strooper, B. Lessons from a failed $\gamma$-secretase Alzheimer trial. Cell 2014, 159 (4), 721-726.

(2) Panza, F.; Lozupone, M.; Solfrizzi, V.; Sardone, R.; Piccininni, C.; Dibello, V.; Stallone, R.; Giannelli, G.; Bellomo, A.; Greco, A.; et al. BACE Inhibitors in clinical development for the treatment of Alzheimer's disease. Expert Rev. Neurother. 2018, 18 (11), $847-$ 857.

(3) Andrews, M.; Tousi, B.; Sabbagh, M. N. 5-HT 6 antagonists in the treatment of Alzheimer's dementia: current progress. Neurol. Ther. 2018, 7 (1), 51-58.

(4) Park, J. H.; Ju, Y. H.; Choi, J. W.; Song, H. J.; Jang, B. K.; Woo, J.; Chun, H.; Kim, H. J.; Shin, S. J.; Yarishkin, O.; et al. Newly developed reversible MAO-B inhibitor circumvents the shortcomings of irreversible inhibitors in Alzheimer's disease. Sci. Adv. 2019, 5 (3), eaav0316.

(5) Bolognesi, M. L. Polypharmacology in a single drug: multitarget drugs. Curr. Med. Chem. 2013, 20 (13), 1639-1645.

(6) Bolognesi, M. L. Harnessing polypharmacology with medicinal chemistry. ACS Med. Chem. Lett. 2019, 10 (3), 273-275.

(7) Jiang, X. Y.; Chen, T. K.; Zhou, J. T.; He, S. Y.; Yang, H. Y.; Chen, Y.; Qu, W.; Feng, F.; Sun, H. P. Dual GSK-3ß/AChE inhibitors as a new strategy for multitargeting antiAlzheimer's disease drug discovery. ACS Med. Chem. Lett. 2018, 9 (3), 171-176.

(8) Kumar, B.; Kumar, V.; Prashar, V.; Saini, S.; Dwivedi, A. R.; Bajaj, B.; Mehta, D.; Parkash, J.; Kumar, V. Dipropargyl substituted diphenylpyrimidines as dual inhibitors of monoamine oxidase and acetylcholinesterase. Eur. J. Med. Chem. 2019, 177, 221234.

(9) Prati, F.; De Simone, A.; Bisignano, P.; Armirotti, A.; Summa, M.; Pizzirani, D.; Scarpelli, R.; Perez, D. I.; Andrisano, V.; Perez-Castillo, A.; et al. Multitarget drug discovery for Alzheimer's disease: triazinones as BACE-1 and GSK-3 $\beta$ inhibitors. Angew. Chem. Int. Ed. Engl. 2015, 54 (5), 1578-1582.

(10) Saavedra, O. M.; Karila, D.; Brossard, D.; Rojas, A.; Dupuis, D.; Gohier, A.; Mannoury la Cour, C.; Millan, M. J.; Ortuno, J. C.; Hanessian, S. Design and synthesis of novel Nsulfonyl-2-indoles that behave as $5-\mathrm{HT}_{6}$ receptor ligands with significant selectivity for $\mathrm{D}_{3}$ over $\mathrm{D}_{2}$ receptors. Bioorg. Med. Chem. 2017, 25 (1), 38-52.

(11) Grychowska, K.; Chaumont-Dubel, S.; Kurczab, R.; Koczurkiewicz, P.; Deville, C.; Krawczyk, M.; Pietruś, W.; Satała, G.; Buda, S.; Piska, K.; et al. Dual 5-HT6 and $\mathrm{D}_{3}$ Receptor antagonists in a group of 1H-pyrrolo[3,2-c]quinolines with neuroprotective and procognitive Aactivity. ACS Chem. Neurosci. 2019, 10, 3183-3196.

(12) Staroń, J.; Kurczab, R.; Warszycki, D.; Satała, G.; Krawczyk, M.; Bugno, R.; Lenda, T.; 
Popik, P.; Hogendorf, A. S.; Hogendorf, A.; et al. Virtual screening-driven discovery of dual $5-\mathrm{HT}_{6} / 5-\mathrm{HT}_{2 \mathrm{~A}}$ receptor ligands with pro-cognitive properties. Eur. J. Med. Chem. 2020, 185, 111857.

(13) Millan, M. J.; Dekeyne, A.; Gobert, A.; Brocco, M.; la Cour, C.; Ortuno, J. C.; Watson, D.; Fone, K. C. F. Dual-acting agents for improving cognition and real-world function in Alzheimer's disease: focus on $5-\mathrm{HT}_{6}$ and $\mathrm{D}_{3}$ receptors as hubs. Neuropharmacology 2020, 108099.

(14) Lalut, J.; Karila, D.; Dallemagne, P.; Rochais, C. Modulating 5-HT 4 and 5-HT 6 receptors in Alzheimer's disease treatment. Future Med. Chem. 2017, 9 (8), 781-795.

(15) Rodríguez-Soacha, D. A.; Scheiner, M.; Decker, M. Multi-Target-Directed-Ligands acting as enzyme inhibitors and receptor ligands. Eur. J. Med. Chem. 2019, 180, 690706.

(16) Simoni, E.; Daniele, S.; Bottegoni, G.; Pizzirani, D.; Trincavelli, M. L.; Goldoni, L.; Tarozzo, G.; Reggiani, A.; Martini, C.; Piomelli, D.; et al. Combining galantamine and memantine in multitargeted, new chemical entities potentially useful in Alzheimer's disease. J. Med. Chem. 2012, 55 (22), 9708-9721.

(17) Incerti, M.; Flammini, L.; Saccani, F.; Morini, G.; Comini, M.; Coruzzi, M.; Barocelli, E.; Ballabeni, V.; Bertoni, S. Dual-Acting drugs: an in vitro study of nonimidazole histamine $\mathrm{H}_{3}$ receptor antagonists combining anticholinesterase activity. ChemMedChem 2010, 5 (7), 1143-1149.

(18) Lalut, J.; Santoni, G.; Karila, D.; Lecoutey, C.; Davis, A.; Nachon, F.; Silman, I.; Sussman, J.; Weik, M.; Maurice, T.; et al. Novel multitarget-directed ligands targeting acetylcholinesterase and $\sigma_{1}$ receptors as lead compounds for treatment of Alzheimer's disease: synthesis, evaluation, and structural characterization of their complexes with acetylcholinesterase. Eur. J. Med. Chem. 2019, 162, 234-248.

(19) Lecoutey, C.; Hedou, D.; Freret, T.; Giannoni, P.; Gaven, F.; Since, M.; Bouet, V.; Ballandonne, C.; Corvaisier, S.; Malzert Fréon, A.; et al. Design of donecopride, a dual serotonin subtype 4 receptor agonist/acetylcholinesterase inhibitor with potential interest for Alzheimer's disease treatment. Proc. Natl. Acad. Sci. 2014, 111 (36), 3825-3830.

(20) Więckowska, A.; Kołaczkowski, M.; Bucki, A.; Godyń, J.; Marcinkowska, M.; Więckowski, K.; Zaręba, P.; Siwek, A.; Kazek, G.; Głuch-Lutwin, M.; et al. Novel MultiTarget-Directed Ligands for Alzheimer's disease: combining cholinesterase inhibitors and 5- $\mathrm{HT}_{6}$ receptor antagonists. Design, synthesis and biological evaluation. Eur. J. Med. Chem. 2016, 124, 63-81.

(21) Youn, Y. H.; Han, Y. G. Primary cilia in brain development and diseases. Am. J. Pathol. 2018, 188 (1), 11-22.

(22) Lesiak, A. J.; Brodsky, M.; Cohenca, N.; Croicu, A. G.; Neumaier, J. F. Restoration of physiological expression of 5-HT 6 receptor into the primary cilia of null mutant neurons lengthens both primary cilia and dendrites. Mol. Pharmacol. 2018, 94 (1), 731-742.

(23) Park, S. M.; Jang, H. J.; Lee, J. H. Roles of primary cilia in the developing brain. Frontiers in Cellular Neurosc. 2019, p 218.

(24) Chaumont-Dubel, S.; Dupuy, V.; Bockaert, J.; Becamel, C.; Marin, P. The 5-HT6 receptor interactome: new insight in receptor signaling and its impact on brain physiology and pathologies. Neuropharmacology 2019, 172, 107839. 
(25) Codony, X.; Vela, J. M.; Ramírez, M. J. 5-HT 6 Receptor and cognition. Curr. Opin. Pharmacol. 2011, 11 (1), 94-100.

(26) de Jong, I. E. M.; Mørk, A. Antagonism of the 5-HT 6 receptor-preclinical rationale for the treatment of Alzheimer's disease. Neuropharmacology 2017, 125 (Supplement C), 50-63.

(27) Ivachtchenko, A. V; Lavrovsky, Y.; Ivanenkov, Y. A. AVN-211, Novel and highly selective $5-\mathrm{HT}_{6}$ receptor small molecule antagonist, for the treatment of Alzheimer's Disease. Mol. Pharm. 2016, 13 (3), 945-963.

(28) Vanda, D.; Soural, M.; Canale, V.; Chaumont-Dubel, S.; Satała, G.; Kos, T.; Funk, P.; Fülöpová, V.; Lemrová, B.; Koczurkiewicz, P.; et al. Novel non-sulfonamide 5-HT 6 receptor partial inverse agonist in a group of imidazo[4,5-b]pyridines with cognition enhancing properties. Eur. J. Med. Chem. 2018, 144, 716-729.

(29) Hogendorf, A. S.; Hogendorf, A.; Kurczab, R.; Kalinowska-Tluscik, J.; Popik, P.; Nikiforuk, A.; Krawczyk, M.; Satala, G.; Lenda, T.; Knutelska, J.; et al. 2Aminoimidazole-based antagonists of the 5- $\mathrm{HT}_{6}$ receptor - a new concept in aminergic GPCR ligand design. Eur. J. Med. Chem. 2019, 179, 1-15.

(30) Morozova, M. A.; Lepilkina, T. A.; Rupchev, G. E.; Beniashvily, A. G.; Burminskiy, D. S.; Potanin, S. S.; Bondarenko, E. V; Kazey, V. I.; Lavrovsky, Y.; Ivachtchenko, A. V. Add-on clinical effects of selective antagonist of 5HT6 receptors AVN-211 (CD-0080173) in patients with schizophrenia stabilized on antipsychotic treatment: pilot study. CNS Spectr. 2014, 19 (4), 316-323.

(31) Schedin-Weiss, S.; Inoue, M.; Hromadkova, L.; Teranishi, Y.; Yamamoto, N. G.; Wiehager, B.; Bogdanovic, N.; Winblad, B.; Sandebring-Matton, A.; Frykman, S.; et al. Monoamine Oxidase B is elevated in Alzheimer Disease neurons, is associated with $\gamma$ secretase and regulates neuronal amyloid $\beta$-peptide levels. Alzheimers. Res. Ther. 2017, 9 (1), 57.

(32) Ramsay, R. R. Molecular aspects of Monoamine Oxidase B. Prog. Neuropsychopharmacol. Biol. Psychiatry 2016, 69, 81-89.

(33) Saura, J.; Luque, J. M.; Cesura, A. M.; Prada, M. Da; Chan-Palay, V.; Huber, G.; Löffler, J.; Richards, J. G. Increased Monoamine Oxidase B activity in plaque-associated astrocytes of Alzheimer brains revealed by quantitative enzyme radioautography. Neuroscience 1994, 62 (1), 15-30.

(34) Tzvetkov, N. T.; Stammler, H. G.; Georgieva, M. G.; Russo, D.; Faraone, I.; Balacheva, A. A.; Hristova, S.; Atanasov, A. G.; Milella, L.; Antonov, L.; et al. Carboxamides vs. methanimines: crystal structures, binding interactions, photophysical studies, and biological evaluation of (Indazole-5-yl)methanimines as Monoamine Oxidase B and Acetylcholinesterase inhibitors. Eur. J. Med. Chem. 2019, 179, 404-422.

(35) Kalinowska-Tłuścik, J.; Staroń, J.; Krawczuk, A.; Mordalski, S.; Warszycki, D.; Satała, G.; Hogendorf, A. S.; Bojarski, A. J. The effect of the intramolecular C-H $\cdots \mathrm{O}$ interactions on the conformational preferences of bis-arylsulfones $-5-\mathrm{HT}_{6}$ receptor antagonists and beyond. RSC Adv. 2018, 8 (33), 18672-18681.

(36) Allen, W. J.; Bevan, D. R. Steered molecular dynamics simulations reveal important mechanisms in reversible Monoamine Oxidase B inhibition. Biochemistry 2011, 50 (29), 6441-6454. 
(37) Binda, C.; Hubálek, F.; Li, M.; Herzig, Y.; Sterling, J.; Edmondson, D. E.; Mattevi, A. Crystal structures of Monoamine Oxidase B in complex with four inhibitors of the Npropargylaminoindan Class. J. Med. Chem. 2004, 47 (7), 1767-1774.

(38) Binda, C.; Hubálek, F.; Li, M.; Herzig, Y.; Sterling, J.; Edmondson, D. E.; Mattevi, A. Binding of Rasagiline-related inhibitors to human Monoamine Oxidases: a kinetic and crystallographic analysis. J. Med. Chem. 2005, 48 (26), 8148-8154.

(39) Tandarić, T.; Vianello, R. Computational insight into the mechanism of the irreversible inhibition of Monoamine Oxidase enzymes by the antiparkinsonian propargylamine inhibitors Rasagiline and Selegiline. ACS Chem. Neurosci. 2019, 10 (8), 3532-3542.

(40) Kohen, R.; Fashingbauer, L. A.; Heidmann, D. E.; Guthrie, C. R.; Hamblin, M. W. Cloning of the mouse $5-\mathrm{HT}_{6}$ serotonin receptor and mutagenesis studies of the third cytoplasmic loop. Brain Res. Mol. Brain Res. 2001, 90 (2), 110-117.

(41) Deraredj Nadim, W.; Chaumont-Dubel, S.; Madouri, F.; Cobret, L.; De Tauzia, M. L.; Zajdel, P.; Benedetti, H.; Marin, P.; Morisset-Lopez, S. Physical interaction between neurofibromin and serotonin $5-\mathrm{HT}_{6}$ receptor promotes receptor constitutive activity. Proc. Natl. Acad. Sci. U. S. A. 2016, 113 (43), 12310-12315.

(42) Grychowska, K.; Satała, G.; Kos, T.; Partyka, A.; Colacino, E.; Chaumont-Dubel, S.; Bantreil, X.; Wesołowska, A.; Pawłowski, M.; Martinez, J.; et al. Novel 1H-pyrrolo[3,2c]quinoline based $5-\mathrm{HT}_{6}$ receptor antagonists with potential application for the treatment of cognitive disorders associated with Alzheimer's Disease. ACS Chem. Neurosci. 2016, 7 (7), 972-983.

(43) Duhr, F.; Déléris, P.; Raynaud, F.; Séveno, M.; Morisset-Lopez, S.; Mannoury la Cour, C.; Millan, M. J.; Bockaert, J.; Marin, P.; Chaumont-Dubel, S. Cdk5 induces constitutive activation of $5-\mathrm{HT}_{6}$ receptors to promote neurite growth. Nat. Chem. Biol. 2014, 10 (7), 590-597.

(44) Di, L.; Kerns, E. H.; Hong, Y.; Kleintop, T. A.; McConnell, O. J.; Huryn, D. M. Optimization of a higher throughput microsomal stability screening assay for profiling drug discovery candidates. J. Biomol. Screen. 2003, 8 (4), 453-462.

(45) Nicotra, A.; Pierucci, F.; Parvez, H.; Senatori, O. Monoamine oxidase expression during development and aging. Neurotoxicology 2004, 25 (1-2), 155-165.

(46) Chen, J. J.; Swope, D. M.; Dashtipour, K. Comprehensive review of rasagiline, a secondgeneration monoamine oxidase inhibitor, for the treatment of parkinson's disease. Clin. Ther. 2007, 29 (9), 1825-1849.

(47) Tavari, M.; Malan, S. F.; Joubert, J. Design, synthesis, biological evaluation and docking studies of sulfonyl isatin derivatives as monoamine oxidase and caspase-3 inhibitors. Med. Chem. Commun. 2016, 7 (8), 1628-1639.

(48) Łażewska, D.; Kurczab, R.; Więcek, M.; Kamińska, K.; Satała, G.; Jastrzębska-Więsek, M.; Partyka, A.; Bojarski, A. J.; Wesołowska, A.; Kieć-Kononowicz, K.; et al. The computer-aided discovery of novel family of the 5 - $\mathrm{HT}_{6}$ serotonin receptor ligands among derivatives of 4-benzyl-1,3,5-triazine. Eur. J. Med. Chem. 2017, 135, 117-124.

(49) Grychowska, K.; Kurczab, R.; Śliwa, P.; Satała, G.; Dubiel, K.; Matłoka, M.; Moszczyński-Pętkowski, R.; Pieczykolan, J.; Bojarski, A. J.; Zajdel, P. Pyrroloquinoline scaffold-based 5- $\mathrm{HT}_{6} \mathrm{R}$ ligands: synthesis, quantum chemical and molecular dynamic studies, and influence of nitrogen atom position in the scaffold on affinity. Bioorg. Med. 
Chem. 2018, 26 (12), 3588-3595.

(50) Glide, Schrodinger, LLC, New York, NY, 2017.

(51) LigPrep, Schrodinger, LLC, New York, NY, 2017.

(52) Epik, Schrodinger, LLC, New York, NY, 2017.

(53) Toledo Warshaviak, D.; Golan, G.; Borrelli, K. W.; Zhu, K.; Kalid, O. Structure-based virtual screening approach for discovery of covalently bound ligands. J. Chem. Inf. Model. 2014, 54 (7), 1941-1950.

(54) Kurczab, R.; Canale, V.; Satała, G.; Zajdel, P.; Bojarski, A. J. Aminoacid hot spots of halogen bonding: a combined theoretical and experimental case study of the $5-\mathrm{HT}_{7}$ receptor. J. Med. Chem. 2018, 61 (19), 8717-8733

(55) Partyka, A.; Kurczab, R.; Canale, V.; Satała, G.; Marciniec, K.; Pasierb, A.; JastrzębskaWięsek, M.; Pawłowski, M.; Wesołowska, A.; Bojarski, A. J.; et al. The impact of the halogen bonding on $\mathrm{D}_{2}$ and $5-\mathrm{HT}_{1 \mathrm{~A}} / 5-\mathrm{HT}_{7}$ receptor activity of azinesulfonamides of 4[(2-ethyl)piperidinyl-1-yl]phenylpiperazines with antipsychotic and antidepressant properties. Bioorganic Med. Chem. 2017, 25 (14), 3638-3648.

(56) Zajdel, P.; Kos, T.; Marciniec, K.; Satała, G.; Canale, V.; Kamiński, K.; Hołuj, M.; Lenda, T.; Koralewski, R.; Bednarski, M.; et al. Novel multi-target azinesulfonamides of cyclic amine derivatives as potential antipsychotics with pro-social and pro-cognitive effects. Eur. J. Med. Chem. 2018, 145, 790-804.

(57) Cheng, Y.; Prusoff, W. H. Relationship between the inhibition constant $\left(K_{\mathrm{i}}\right)$ and the concentration of inhibitor which causes 50 per cent inhibition $\left(\mathrm{IC}_{50}\right)$ of an enzymatic reaction. Biochem. Pharmacol. 1973, 22 (23), 3099-3108.

(58) Stössel, A.; Schlenk, M.; Hinz, S.; Küppers, P.; Heer, J.; Gütschow, M.; Müller, C. E. Dual targeting of adenosine $A_{2 A}$ receptors and monoamine oxidase B by $4 \mathrm{H}-3,1$ benzothiazin-4-ones. J. Med. Chem. 2013, 56 (11), 4580-4596.

(59) Łażewska, D.; Olejarz-Maciej, A.; Reiner, D.; Kaleta, M.; Latacz, G.; Zygmunt, M.; Doroż-Płonka, A.; Karcz, T.; Frank, A.; Stark, H.; et al. Dual target ligands with 4-tertbutylphenoxy scaffold as histamine $\mathrm{H}_{3}$ receptor antagonists and monoamine oxidase $\mathrm{B}$ inhibitors. Int. J. Mol. Sci. 2020, 21 (10), 3411-3431.

(60) Jiang, L. I.; Collins, J.; Davis, R.; Lin, K. M.; DeCamp, D.; Roach, T.; Hsueh, R.; Rebres, R. A.; Ross, E. M.; Taussig, R.; et al. Use of a CAMP BRET sensor to characterize a novel regulation of cAMP by the sphingosine 1-phosphate/G13 pathway. J. Biol. Chem. 2007, 282 (14), 10576-10584.

(61) Singh, J. K.; Solanki A, S. V. Comparative in vitro intrinsic clearance of imipramine in multiple species liver microsomes: human, rat, mouse and dog. J Drug Metab Toxicol 2012, 3, 126.

(62) Sumantran, V. N. Cellular Chemosensitivity Assays: An Overview. Methods Mol. Biol. 2011, 731, 219-236.

(63) Ennaceur, A.; Delacour, J. A new one-trial test for neurobiological studies of memory in rats. 1: Behavioral data. Behav. Brain Res. 1988, 31 (1), 47-59.

(64) Popik, P.; Holuj, M.; Nikiforuk, A.; Kos, T.; Trullas, R.; Skolnick, P. 1Aminocyclopropanecarboxylic acid (ACPC) produces procognitive but not antipsychotic-like effects in rats. Psychopharmacology (Berl). 2015, 232 (6), 10251038. 
